\title{
JOGANDO COM OS PRECEDENTES: REGRAS, ANALOGIAS, PRINCÍPIOS
}

\author{
Antonio Moreira Maués
}

PLAYING WITH PRECEDENTS: RULES, ANALOGIES, PRINCIPLES

\section{RESUMO}

ESTE ARTIGO ANALISA DECISÕES RECENTES DO STF ENVOLVENDO A APLICAÇÃO DE SÚMULAS VINCULANTES À LUZ DE TRÊS CONCEPCÕES DE PRECEDENTES, DESENVOLVIDAS POR F. Schauer (PRECEDENTES COMO REgRAS), C. SUNSTEIN (PRECEDENTES COMO ANALOGIAS) E R. DWORKIN (PRECEDENTES COMO PRINCÍPIOS). APÓS A EXPOSIC̣ÃO DOS PRINCIPAIS ASPECTOS DE CADA UMA DESSAS TEORIAS BASEADAS, RESPECTIVAMENTE, NOS CONCEITOS DE GENERALIZAÇÕES ENRAIZADAS, ACORDOS TEÓRICOS INCOMPLETOS E ROMANCE EM CADEIA, E DISCUTE OS FUNDAMENTOS QUE ELAS PODEM OFERECER PARA O USO DE PRECEDENTES NO DIREITO BRASILEIRO.

\section{PALAVRAS-CHAVE}

Precedentes; Supremo Tribunal Federal; Súmulas VINCULANTES.

\section{ABSTRACT}

THIS ARTICLE ANALYSES THE USE OF BINDING PRECEDENTS BY THE BRAZILIAN SUPREME COURT IN THE LIGHT OF THREE CONCEPTIONS OF PRECEDENTS, WHICH ARE DEVELOPED BY F. SCHAUER (PRECEDENTS AS RULES), C. SUNSTEIN (PRECEDENTS AS ANALOGIES) AND R. DWORKIN (PRECEDENTS AS PRINCIPLES). AFTER THE EXPOSITION OF THE MAIN ASPECTS OF EACH THEORY, BASED RESPECTIVELY ON THE CONCEPTS OF ENTRENCHED GENERALIZATIONS, INCOMPLETELY THEORIZED AGREEMENTS AND CHAIN NOVEL, THE ARTICLE DEBATES THE ARGUMENTS THAT THEY CAN PROVIDE FOR THE USE OF PRECEDENTS IN BRAZILIAN LAW.

\section{KEYWORDS}

Precedents: BrazILIAN SUPREME CoUrt: BINDING PRECEDENTS.

\section{INTRODUÇÃO}

A partir da adoção do efeito vinculante e da súmula vinculante no Brasil, os precedentes judiciais do STF passaram a ser objeto central de estudo do direito constitucional. Uma das principais preocupações observadas na literatura, desde então, dirige-se para estabelecer critérios que permitam tipificar as diferentes espécies de precedentes existentes no direito brasileiro. Embora as classificações apresentadas divirjam quanto à terminologia, um ponto comum entre elas aparece na identificação de um tipo de precedente que se caracteriza como "aquele que deve ser seguido, mesmo que o Juiz ou Tribunal o considere incorreto ou irracional" (SOUZA, 2006, p. 55), ou "estabelece um entendimento que deverá ser obrigatoriamente seguido em casos análogos" 
(MELLO, 2008, p. 104) ou ainda devido à "circunstância de o juiz não poder revogar a decisão, ainda que tenha bons fundamentos para não respeitá-la” (MARINONI, 2010, p. 112). Dessa forma, a vinculação produzida pelas súmulas e decisões do STF é vista como um dever que impede os juízes de examinarem, de modo amplo, a correção da aplicação do precedente ao caso atual.

Embora essas análises reconheçam que os juízes podem fazer distinções (distinguishing) dos casos no momento de aplicação dos precedentes, elas tendem a restringir o papel do poder judiciário e do próprio STF nesse campo, pois sua concepção das súmulas e decisões vinculantes implica defender que haja limites em sua interpretação, mesmo que existam boas razões para não aplicá-lo, o juiz está obrigado a seguir o precedente. O exame da jurisprudência do STF, no entanto, mostra um quadro distinto, tal como exemplificam as decisões a seguir sobre súmulas vinculantes.

A Súmula Vinculante n. 3 possui a seguinte redação:

Nos processos perante o Tribunal de Contas da União asseguram-se o contraditório e a ampla defesa quando da decisão puder resultar anulação ou revogação de ato administrativo que beneficie o interessado, excetuada a apreciação da legalidade do ato de concessão inicial de aposentadoria, reforma e pensão.

De acordo com os precedentes dessa súmula, ${ }^{1}$ a exceção posta no final justificava-se porque a concessão de aposentadoria ou pensão constitui ato administrativo complexo que somente se aperfeiçoa com o registro definitivo pelo Tribunal de Contas da União (TCU), após o julgamento de sua legalidade, o qual, por constituir exercício da competência constitucional do controle externo (art. 71, III), é feito de ofício e ocorre sem a participação dos interessados e, portanto, sem direito ao contraditório e à ampla defesa.

Pouco tempo após a edição dessa súmula,$^{2}$ no entanto, o TCU foi obrigado a reavaliar, no julgamento do MS n. 25.116, a exceção disposta ao seu final. Tratava-se de um caso em que o TCU havia negado o registro da aposentadoria de funcionário do IBGE, ocupante do cargo de professor na Escola Nacional de Ciências Estatísticas, sob o fundamento de que havia sido feito indevidamente o cômputo de serviço prestado sem contrato formal sem recolhimento das contribuições previdenciárias. ${ }^{3}$ A partir do reconhecimento de que a recusa do registro ocorrera quase seis anos após a concessão da aposentadoria, o Ministro Carlos Ayres, relator, realizou uma "análise mais detida" do caso, a fim de identificar se o lapso de tempo havia gerado estabilidade ao ato. Nessa toada, o Ministro reconheceu que a manifestação do controle externo deveria se formalizar em prazo razoável, que deveria ser estabelecido em cinco anos, de acordo com o critério temporal utilizado em outras normas presentes no ordenamento jurídico. ${ }^{4}$ Dentro desse prazo, não seria necessário a 
convocação do interessado para participar do processo, contudo, caso o TCU não se manifestasse no período, passaria a haver direito líquido e certo do indivíduo ao contraditório e à ampla defesa. ${ }^{5}$

Dessa argumentação resultou uma nova interpretação da SV n. 3, que inclui a garantia do contraditório e dá ampla defesa, mesmo nos casos de registro de aposentadoria, reforma e pensão, desde que transcorridos cinco anos do ato inicial. O fundamento dessa distinção encontra-se expresso na ementa do acórdão:

Esse aspecto temporal diz intimamente com: a) o princípio da segurança jurídica, proteção objetiva do princípio da dignidade da pessoa humana e elemento conceitual do Estado de Direito; b) a lealdade, um dos conteúdos do princípio constitucional da moralidade administrativa (caput do art. 37 ). ${ }^{6}$

Caso similar ao anterior ocorreu com a SV n. 5, segundo a qual: "A falta de defesa técnica por advogado no processo administrativo disciplinar não ofende a Constituição”. Cabe observar que não havia congruência entre esse enunciado e os precedentes do STF que foram invocados como seus fundamentos. ${ }^{7}$ Nos debates sobre a edição da súmula, ${ }^{8}$ os próprios Ministros reconheceram que não havia decisões reiteradas sobre a matéria, contudo, a existência de enunciado em sentido contrário do Superior Tribunal de Justiça (STJ) ${ }^{9}$ fez com que o STF decidisse sumular seu entendimento para impedir a multiplicação de recursos sobre a questão. Em consequência, a forma pouco matizada com que a súmula foi redigida trouxe problemas para sua aplicação, o que obrigou o STF a esclarecer seu entendimento no julgamento do RE n 398.269. Nesse caso, o TJ-RS havia mantido a regressão do regime de cumprimento da pena para fechado, baseado no cometimento de falta grave (fuga) apurada em processo administrativo disciplinar, embora não tenha havido defesa técnica. A solução dada pelo Ministro Gilmar Mendes, relator, é peremptória: nessa situação, a prática de ato de defesa sem a presença de defensor viola o princípio do contraditório e da ampla defesa. Assim, a edição da SV n. 5 não havia alterado a orientação já firmada pelo STF quanto à nulidade do processo administrativo disciplinar de natureza penal que não observa as garantias constitucionais. A razão dessa distinção dos procedimentos instaurados no âmbito da execução penal, nos quais a defesa técnica é indispensável, encontra-se no fato de estar em jogo "o direito fundamental à liberdade de ir e vir". A necessidade dessa interpretação do STF demonstra-se no próprio voto do Ministro Gilmar Mendes, que constata a "erronia” na aplicação da SV n. 5. ${ }^{10}$

O terceiro caso envolve a SV n. 13:

A nomeação de cônjuge, companheiro ou parente em linha reta, colateral ou por afinidade, até o terceiro grau, inclusive, da autoridade nomeante ou de servidor da 
mesma pessoa jurídica investido em cargo de direção, chefia ou assessoramento, para o exercício de cargo em comissão ou de confiança ou, ainda, de função gratificada na administração pública direta e indireta em qualquer dos poderes da União, dos Estados, do Distrito Federal e dos Municípios, compreendido o ajuste mediante designações recíprocas, viola a Constituição Federal.

A extensa redação da súmula revela as dificuldades enfrentadas pelo STF para editar um enunciado compatível com seus precedentes. ${ }^{11}$ Em um deles, o RE n. 579.951, o Tribunal já havia feito uma distinção entre "cargos estritamente administrativos", regidos pelo art. 37 da CR, e "cargos políticos" (ministros, secretários de estado e secretários municipais), regidos com base no art. 76 da CR, considerando que, nesses últimos, a liberdade de escolha do Chefe do Executivo, para a formação do governo, permite a nomeação de parentes, desde que não haja violação do princípio da moralidade administrativa. Tal entendimento foi ratificado pelo STF em várias reclamações ( $\mathrm{Rcl}$. n. 6.650, Rcl. n. 7.602, Rcl. n. 7.834, Rcl. n. 7.590, Rcl. n. $8.005),{ }^{12}$ sem excluir a possibilidade de análise de circunstâncias que poderiam consubstanciar caso de nepotismo e levar à aplicação da SV n. 13 inclusive a nomeações para cargos políticos. ${ }^{13}$

Decisões como essas ${ }^{14}$ dificultam o enquadramento da jurisprudência do STF em uma única concepção sobre precedentes. A vinculação estabelecida pelas súmulas não impede que o Tribunal examine um conjunto de razões para decidir se estas se aplicam ou não ao caso.

Tal atitude interpretativa do STF nos desafia a desenvolver uma análise mais apurada sobre o tema, a fim de buscar os possíveis fundamentos teóricos da jurisprudência do Tribunal e elaborar critérios que possam justificar as distinções feitas por ele. Não se trata, portanto, de apresentar uma concepção de precedente que seja considerada abstratamente a mais correta, mas sim de partir da jurisprudência como base de uma reflexão sobre a adequação das várias concepções existentes ao direito brasileiro. 15

Neste artigo, nosso objetivo será analisar, com base nas obras de F. Schauer, C. Sunstein e R. Dworkin, três diferentes concepções de precedentes encontrados no direito norte-americano, nomeados por nós, respectivamente, de precedentes como regras, como analogias e como princípios. ${ }^{16} \mathrm{~A}$ escolha dessas teorias justificase pela profundidade do debate sobre precedentes que a tradição do stare decisis permite que seja desenvolvido naquele sistema jurídico, o que inclui a reflexão crítica sobre as razões que os justificam.

Após a apresentação de cada teoria, analisaremos os argumentos que elas apresentam a seu favor, de modo a refletir sobre quais fundamentos essas concepções podem oferecer para a aplicação das decisões e súmulas vinculantes no direito brasileiro. ${ }^{17}$ 


\section{Precedentes como regras: Schauer e as Generalizações}

ENRAIZADAS (ENTRENCHED BENERALIZATIONS)

Em sua obra principal, Playing by the Rules, Frederick Schauer (1991) se propõe a analisar o papel exercido pelas regras de caráter prescritivo nos processos de tomada de decisão, especialmente no campo do direito. ${ }^{18}$ Regras prescritivas, como "Não matarás" ou "Cintos de segurança devem estar afivelados" são utilizadas para impor pressão (apply pressure) sobre o mundo. Essa pressão normativa pode ser exercida de diferentes formas, tanto para alterar algum padrão de comportamento preexistente, como no caso do sinal de trânsito "Pare", quanto para evitar uma mudança de comportamento, reforçando padrões de conduta preexistentes, como os códigos de honra militares. Em ambas as situações, as regras prescritivas pressionam os agentes a não se desviarem de seus mandamentos. ${ }^{19}$

Segundo Schauer (1991, p. 3-6), há duas espécies de regras prescritivas: as instruções (instructions) e as regras obrigatórias (mandatory rules). O autor chama de instruções as regras prescritivas que nos orientam sobre como executar uma determinada tarefa ou atividade para se obter êxito, por exemplo: "Verifique a temperatura antes de colocar a panela no forno". Esse tipo de regra se caracteriza por ser duplamente opcional. Em primeiro lugar, as instruções somente se aplicam àqueles casos em que o agente, embora deseje ter êxito em um determinado curso de ação, não é obrigado a segui-lo. Ao contrário de regras como "É proibido estacionar de 9 às 18 horas”, as instruções contêm, expressa ou implicitamente, uma cláusula "se", que limita sua aplicação aos agentes que optam por praticar determinada ação. ${ }^{20}$

As instruções são também opcionais porque sua força depende de que seja provável que elas produzam o resultado desejado. Quando o agente avalia que, em determinado caso, a instrução não levará ao resultado, ele se sente livre para ignorála e fazer o que considera melhor. As instruções, portanto, funcionam como regras de experiência (rules of thumb) que fornecem orientações úteis para situações de rotina, mas deixam de impor pressão normativa, caso não sejam válidas para a obtenção de determinados resultados.

A descrição do caráter opcional das regras de experiência é importante porque permite a Schauer distinguir as situações em que a força de uma regra não é considerada totalmente opcional pelo agente, nem depende de seu valor em um contexto particular. Tais regras, que constituem o principal objeto da reflexão desse autor, são chamadas por ele de regras obrigatórias e se definem como aquelas que fornecem razões para agir simplesmente em virtude de sua existência como regras, exercendo pressão normativa inclusive naqueles casos em que o resultado não esteja de acordo com a justificativa da regra. Assim, mesmo que haja fortes razões para agir de modo contrário ao que uma regra obrigatória prescreve, isso não é suficiente para deixar de aplicá-la. 


\section{I REgRAS COMO GENERALIZAÇÕES ENRAIZADAS}

A partir dessas definições, Schauer (1991, p. 17-27) observou que tanto as regras descritivas quanto as prescritivas operam por meio de generalizações, lidando com tipos e não com casos particulares. As regras descritivas registram ou explicam uma regularidade que pressupõe a existência de múltiplos exemplos, enquanto as regras prescritivas se aplicam a múltiplas ações.

Isso significa que as regras precisam utilizar categorias para agrupar os casos particulares, que passam a ser vistos como membros de uma determinada classe. Contudo, as categorias que permitem a generalização não podem ser diferenciadas rigidamente, uma vez que possuem áreas de interseção ou justaposição umas com as outras, o que faz com que um objeto ou acontecimento particular integre, simultaneamente, várias categorias. Um cachorro, por exemplo, pode ser agrupado de acordo com sua raça, cor, local de moradia, além de várias outras propriedades, o que torna necessário escolher em que direção e em que grau de abstração a generalização será feita. ${ }^{21}$

A identificação da generalização como característica das regras, permite a Schauer reformular a estrutura binária das regras prescritivas, cujos componentes são chamados por ele de "predicado factual" e "consequente". O primeiro elemento especifica o âmbito da regra, as condições factuais que propiciam sua aplicação, podendo ser formulado como uma hipótese do tipo "se X”, onde X é uma sentença cuja verdade é condição necessária e suficiente para a aplicação da regra, tal como no exemplo "Se alguém dirige acima de 55 milhas por hora, deverá pagar uma multa de 50 dólares”. Já o consequente prescreve o que vai acontecer caso se verifiquem as condições especificadas no predicado factual. ${ }^{22}$

Feita essa distinção, Schauer pode afirmar que o predicado factual de uma regra prescritiva é composto por uma generalização. Ao contrário de uma ordem ${ }^{23}$ que proíba, por exemplo, um cão chamado "Angus" de entrar em um restaurante em determinada ocasião, uma regra estabeleceria que "É proibido a entrada de cães no restaurante". Neste caso, o predicado factual "cães no restaurante" é uma generalização que alcança todos os cães em qualquer situação. Mesmo que a generalização seja mais restrita, proibindo a entrada somente de uma determinada raça de cães, ainda assim a regra usará seu predicado factual para aplicar-se a todos os casos particulares nele contidos.

Como a generalização resulta de uma escolha, Schauer afirma que, normalmente, as regras prescritivas são formuladas a partir de um caso particular que é tomado como exemplo de uma categoria mais geral. Busca-se, então, a propriedade do particular que é causalmente relevante para a ocorrência daquela categoria. No caso da regra proibindo a entrada de cães no restaurante, essa categoria mais geral poderia ser o desejo de evitar a repetição dos incômodos aos clientes que foram provocados pela presença de um determinado cão no local. 
A categoria mais geral, portanto, fornece a justificativa da regra, indicando o mal que se quer evitar ou o objetivo que se quer alcançar com ela. É a justificativa que determina, dentre as várias opções possíveis, qual generalização de um acontecimento particular será escolhida como o predicado factual da regra. No exemplo de Schauer, embora a cor preta do cão que entrou no restaurante também seja uma propriedade do acontecimento, ela não é relevante para a justificativa da regra, uma vez que foi ela que provocou incômodos nos clientes.

\section{I . I . I EXPERIÊNCIAS RECALCITRANTES}

A coerência entre a generalização contida no predicado factual das regras prescritivas e sua justificativa não evita, contudo, o surgimento de problemas (SCHAUER, 1991, p. 31-41). O primeiro deles aparece quando a generalização inclui propriedades que, em determinadas situações, serão irrelevantes para a justificativa, ou quando exclui propriedades que, em outras situações, serão relevantes para a justificativa. Tal problema decorre do fato de que a relação de causa e efeito que se busca estabelecer entre o predicado factual e sua justificativa não é de caráter necessário, mas sim probabilístico, indicando que determinada propriedade possui maiores possibilidades de provocar determinado resultado. Assim, a regra que proíbe a entrada de cães no restaurante não exclui que alguns cães possam não incomodar os clientes; a regra que proíbe dirigir a uma velocidade superior a 55 milhas não exclui que alguém possa ultrapassar de modo seguro esse limite; e a regra que proíbe o consumo de bebidas alcoólicas por menores de 21 anos não exclui que algumas pessoas abaixo dessa idade possam beber com responsabilidade. Paralelamente, outros animais, que não cães, podem incomodar os clientes de um restaurante; a direção perigosa pode resultar de outros fatores além do excesso de velocidade; e pessoas maiores de 21 anos podem consumir álcool de maneira irresponsável.

No primeiro conjunto de casos, a generalização do predicado factual da regra é sobreinclusiva (over-inclusive), pois incorpora propriedades que, em determinadas situações, podem não provocar a consequência que corresponde à justificativa da regra. No segundo conjunto, a generalização do predicado factual é subinclusiva (under-inclusive), pois não abrange propriedades que, em determinadas situações, podem provocar a consequência que corresponde à justificativa da regra. Em uma generalização sobreinclusiva, o predicado factual inclui características do caso que não atendem à justificativa da regra; em uma generalização subinclusiva, o predicado factual deixa de reconhecer características do caso que atenderiam à justificativa da regra.

Para Schauer, mesmo que fosse possível haver generalizações que se ajustassem perfeitamente à justificativa da regra, isso não evitaria um segundo problema. A possibilidade de que um predicado factual inclua todas as propriedades relevantes para a produção de determinado resultado e exclua todas as propriedades irrelevantes está ligada à nossa percepção do mundo em determinado momento, a qual pode mudar. 
$\mathrm{Na}$ hipótese de que todos os seres humanos tivessem uma violenta reação alérgica a qualquer tipo de cachorro, e somente cachorros provocassem esse determinado tipo de reação, a regra que proíbe cães não seria nem sobreinclusiva, nem subinclusiva, tendo em conta que sua justificativa residiria na prevenção dessa reação. Contudo, se novos conhecimentos indicassem que uma raça de cachorros desconhecida não possui o agente alérgico, ou que algumas pessoas são imunes a essas reações, isso faria com que a presumida precisão da regra fosse falsificada por esse novo conhecimento. Como os seres humanos são falíveis e têm um conhecimento imperfeito das mudanças que ocorrerão no futuro, uma vez que o próprio mundo é variável, as regras que se baseiam em uma relação empírica entre a generalização e justificativa permanecem vulneráveis a descobertas posteriores ou a acontecimentos que venham falsificar o que fora previamente concebido como uma verdade universal. Portanto, mesmo a regra de maior precisão é potencialmente imprecisa. ${ }^{24}$

Os problemas indicados por Schauer são chamados de "experiências recalcitrantes”, pois colocam em xeque a adequação a casos particulares das generalizações feitas pelas regras, que, normalmente, atendem às nossas necessidades. ${ }^{25}$ Para lidar com os problemas que decorrem da disjunção entre a generalização e a justificativa da regra, esse autor apresenta dois modelos: o modelo da conversação e o modelo do enraizamento.

Quando uma experiência recalcitrante ocorre durante uma conversação, em que os participantes podem corrigir os equívocos que surgem em seu decorrer, as imperfeições da linguagem representam pouco mais do que barreiras temporárias ao entendimento e à compreensão. Se as circunstâncias de uma conversa requerem maior precisão do que a que foi oferecida por meio de uma generalização, os participantes podem fornecer as qualificações e os detalhamentos necessários. Por exemplo, a afirmação de que dirigir acima de 55 milhas por hora é perigoso não impede, caso a conversação exija, que eu a qualifique dizendo que motoristas especialmente treinados podem dirigir acima de 55 milhas de modo seguro ou que, sob algumas condições, dirigir abaixo de 55 milhas pode ser igualmente perigoso.

Portanto, as qualificações oferecidas durante uma conversação ocupam o espaço da sobreinclusão e da subinclusão de uma generalização, evitando as confusões que aparecem quando consideramos essas generalizações como universais, e não probabilísticas. Do mesmo modo, o modelo da conversação também oferece soluções ao problema da textura aberta, pois pode fazer com que nossa linguagem mude para se adaptar a uma nova realidade até então desconhecida, permitindo que uma propriedade suprimida pela generalização volte à conversa se as circunstâncias assim demandarem.

Embora a adaptabilidade inerente ao modelo da conversação permita aos participantes continuamente esclarecerem o que estão dizendo, Schauer observa que esse modelo é, em grande parte, ideal. Na realidade, algumas generalizações se tornam enraizadas, o que impede que a linguagem seja infinitamente sensível e adaptável. ${ }^{26}$ 
Sob o modelo do enraizamento, portanto, as possibilidades de adaptação às experiências recalcitrantes encontram-se limitadas pelo fato de que as generalizações existentes conduzem nosso entendimento e nossa capacidade de observação em algumas direções, enquanto os afastam de outras. Quando as generalizações estão enraizadas, certas opções nunca serão vistas, outras serão difíceis de serem expressas e outras ainda vão se tornar menos compreensíveis.

\section{I.I. 2 O ENRAIZAMENTO DAS GeneralizaÇÕ̃es PRESCRITIVAS}

A distinção entre o modelo da conversação e o modelo do enraizamento foi especialmente útil para que Schauer (1991, p. 42-52) expusesse sua teoria sobre as regras. Ao projetarem para um futuro desconhecido as generalizações feitas no passado, as regras prescritivas sujeitam-se às experiências recalcitrantes já apresentadas. Sob o modelo da conversação, a generalização contida no predicado factual da regra seria modificada para dar conta do problema, incorporando as particularidades agora consideradas relevantes. De modo contrário, sob o modelo do enraizamento, a ocorrência de uma experiência recalcitrante, embora conflite com a generalização anterior, não provoca sua reformulação. Uma generalização enraizada continua a controlar a decisão mesmo diante de uma experiência recalcitrante: o resultado indicado pela generalização prevalece contra o resultado indicado pela experiência recalcitrante como mais apropriado para o caso em questão.

Se lembrarmos a regra "É proibido a entrada de cães no restaurante", veremos que seu predicado factual inclui todos os cães, e não apenas aqueles cujas ações trariam incômodos aos clientes. Ela impede a entrada, por exemplo, de cães-guia, em relação aos quais poderia haver razões para não aplicá-la, uma vez que as diferenças entre os vários tipos de cachorro não são consideradas relevantes por seu predicado factual. Como vimos, tal relevância é determinada pela justificativa da regra, mas a regra suprime diferenças que seriam válidas do ponto de vista de sua própria justificativa. Supondo que essa justificativa seja impedir que os clientes sejam incomodados por cães, a regra pressupõe uma generalização probabilística de que muitos cachorros se comportam mal, mas ela é sobreinclusiva em relação a cães que não causariam incômodos, tal como no exemplo dado.

Caso essa regra seja compreendida com base no modelo da conversação, o aparecimento de um cão-guia na entrada do restaurante faria com que a regra fosse adaptada àquela situação, uma vez que a experiência recalcitrante demonstraria que ela não atende à sua justificativa. Desse modo, as aplicações da regra nunca a divergiriam de sua justificativa. Sob o modelo do enraizamento, contudo, a generalização preexistente seria tratada exatamente dessa maneira, como algo enraizado, e controlaria a decisão mesmo naqueles casos em que ela deixa de atender à justificativa da regra. Nesse modelo, o enraizamento do predicado factual “cães" também proibiria a entrada no restaurante de cães-guia. ${ }^{27}$ 
Com esses elementos, Schauer pôde distinguir dois processos de tomada de decisão, cujas diferenças tornam-se nítidas quando surge uma experiência recalcitrante, ou seja, quando a aplicação de uma regra não produz o resultado que estaria de acordo com sua justificativa. No primeiro processo, chamado de particularista, a autoridade encarregada da decisão trata da generalização pré-existente da regra como se ela surgisse em uma conversação, modificando-a sempre que não fosse fiel à sua justificativa. A generalização funciona apenas como um indicador da justificativa da regra, e não exerce nenhuma pressão normativa quando o exame direto da justificativa nos diz qual é o resultado correto. Assim, o indicador "cães" será aplicado somente aos cães cuja exclusão do restaurante for necessário para não causar incômodos aos clientes.

No segundo processo de tomada de decisão, a autoridade trata a regra como enraizada, prescrevendo a decisão que deve ser adotada mesmo nos casos em que ela contraria sua justificativa, caso ela fosse diretamente aplicada. Nesse processo, a generalização não é apenas um indicador, mas oferece à autoridade razões para decidir que são independentes das razões fornecidas pela justificativa da regra. Para Schauer, essa segunda forma caracteriza o processo de decisão baseado em regras: é exatamente quando ocorre uma disjunção entre a generalização da regra e sua justificativa que podemos compreendê-lo de modo mais apurado.

\section{I.2 Precedentes como generalizações enraizadas}

Com base no conceito de regras como generalizações enraizadas, Schauer (1991, p. 174-187) desenvolveu sua teoria dos precedentes. Segundo ele, nos sistemas de common law, em que os juízes decidem aplicando os princípios que justificam decisões anteriores, algumas dessas justificativas tornam-se recorrentes com o passar do tempo, levando ao desenvolvimento de um conjunto de prescrições gerais que aparecem como regras e, assim, são tratadas pelos juristas. Embora tais regras não estejam codificadas, elas são coercitivas e vinculam os juízes.

Schauer reconhece que uma das características que distinguem o common law é a possibilidade de que as regras que integram o sistema sejam modificadas se o caso assim o exigir, isto é, quando o juiz entender que a aplicação da regra não é consistente com sua justificativa ou não representa uma boa política. Caso isso sempre ocorresse, argumenta o autor, não haveria regras prescritivas no common law, uma vez que elas não poderiam impor nenhum tipo de obrigação. Assim, o sistema seria baseado em decisões de acordo com justificativas, uma vez que as "regras" somente seriam aplicadas a novos casos se fossem consistentes com o conjunto de políticas e princípios do sistema. Todas as generalizações nele contidas seriam consideradas contingentes e possíveis de aperfeiçoamento.

Essa visão não corresponde, contudo, aos sistemas de common law realmente existentes. Na prática, esses sistemas funcionariam de modo menos instrumental e mais 
formalista, tratando o entendimento geral que existe sobre uma regra como algo que se aplica ao caso ao menos presuntivamente. Tais interpretações, formuladas como sínteses de um conjunto de decisões anteriores, possuem peso normativo mesmo quando suas justificativas de fundo não forem atendidas. Portanto, as regras do common law também operam como regras no sentido exposto por Schauer, uma vez que suas formulações se tornam enraizadas e seu sentido determina - ou ao menos influencia - a decisão dos casos subsequentes mais do que a aplicação de suas justificativas.

Para Schauer, os precedentes constituem a maneira pela qual as regras se tornam enraizadas no common law. De acordo com sua análise, um sistema de precedentes parte da ideia de que o tratamento anterior X, dado à situação A, constitui, somente por causa de seu valor histórico, uma razão para tratar $\mathrm{A}$ do modo $\mathrm{X}$ se e quando A ocorra novamente. O contraponto do argumento baseado no precedente é fornecido pelo argumento baseado na experiência. Quando raciocinamos a partir da experiência - tal como um médico que diagnostica uma doença diante do aparecimento de certos sintomas - seu valor depende da probabilidade de que o presente seja semelhante ao passado, pois, se chegarmos à conclusão de que o caso atual é diferente, a experiência anterior deixa de ser relevante. Além disso, se considerarmos que as decisões tomadas no passado estavam equivocadas, a experiência perde completamente seu valor. No caso do argumento do precedente, o fato de que algo tenha sido decidido anteriormente lhe confere peso decisório no presente, mesmo que julguemos que essa decisão estava errada.

Quando a força de uma conclusão atual se baseia integralmente em argumentos a favor ou contra ela, Schauer considera que não há recurso ao precedente, embora a mesma conclusão possa ter sido obtida no passado. Para que o precedente seja relevante, é necessário que a decisão anterior continue influenciando a decisão atual, mesmo que ela seja julgada incorreta, o que significa que o argumento do precedente funciona, essencialmente, como o argumento da regra. Da mesma maneira que o argumento da regra confere um peso independente ao resultado por ela indicado, o argumento do precedente confere um peso independente ao resultado que se assemelha àquele obtido no passado, razão pela qual ele é considerado vinculante (authoritative) e não apenas persuasivo. ${ }^{28}$

Schauer concluiu que as regras que derivam dos precedentes são um subconjunto das regras prescritivas, e as discussões sobre o peso e status das regras também se aplicam aos precedentes. 29

\section{Precedentes como analogias: Sunstein e os acordos teóricos} INCOMPLETOS (INCOMPLETELY THEORIZED AGREEMENTS)

A teoria de Cass Sunstein (1996) foi desenvolvida sobre o pano de fundo das democracias ocidentais contemporâneas, as quais, segundo o autor, caracterizam-se por 
sua heterogeneidade e pela existência de profundas divergências sobre os princípios que devem reger a sociedade. Desacordos sobre o papel da religião na esfera pública, sobre as concepções de liberdade e igualdade, sobre os fundamentos da liberdade de expressão e do direito de propriedade, sobre as relações de gênero, são apenas alguns exemplos dos conflitos com os quais as democracias estão obrigadas a conviver, uma vez que todos os pontos de vista presentes na sociedade sobre essas e outras questões merecem ser respeitados.

Nesse ambiente de divergência de princípio e exigência de respeito mútuo, Sunstein (1996, p. 4-6) defende que os juízes - que também adotam diferentes posições sobre temas fundamentais -, devem decidir as controvérsias com base em acordos teóricos incompletos, a fim de gerar estabilidade social em meio à diversidade. Tais acordos caracterizam-se por trabalhar mais com resultados concretos do que com abstrações, o que permite obter concordância mesmo entre pessoas que pensam diferente.

Para esse autor, podemos encontrar essa forma de acordo em várias situações. Por exemplo, a defesa das espécies ameaçadas pode ser feita com base em diferentes razões: a existência de obrigações dos seres humanos com a natureza, a importância dessas espécies para o equilíbrio ecológico ou mesmo para a produção de medicamentos. De modo similar, a responsabilidade objetiva pode ser justificada por diferentes teorias: eficiência econômica, fins distributivos ou concepções de direitos fundamentais.

Nos acordos teóricos incompletos, os participantes concordam com o resultado, mesmo sem concordar com a teoria mais geral que pode justificá-lo. Deixando de lado os princípios mais abstratos, as pessoas podem estar de acordo com uma regra - reduzir a poluição da água, permitir a sindicalização de trabalhadores -, ou podem aceitar um resultado - manutenção do direito ao aborto, proteção de formas de arte sexualmente explícitas -, mesmo sem convergir sobre seus fundamentos. No âmbito judicial, isso significa que a concordância sobre uma determinada decisão não exige que os juízes compartilhem uma mesma teoria geral, o que é especialmente importante tendo em vista que, em uma sociedade democrática, o judiciário não deve substituir o processo político na definição dos princípios fundamentais.

\section{I Ferramentas do Raciocínio JURídico}

Para demonstrar como os acordos teóricos incompletos operam no mundo do direito, Sunstein (1996, p. 13-34) desenvolveu uma análise dos instrumentos utilizados pelos juristas para desenvolver seus raciocínios. Como ponto de partida, esse autor afirma que, embora o direito compartilhe da mesma lógica empregada por outras formas de pensamento, o discurso jurídico possui seu próprio vocabulário e suas próprias convenções, que lhe impõem determinados limites. Além disso, as práticas que moldam o raciocínio jurídico dificilmente podem ser reduzidas a algumas poucas regras, uma vez que constituem um conjunto de pressupostos que tornam possível a interpretação do 
direito. Por exemplo, palavras como "liberdade religiosa" ou "práticas mercantis abusivas” podem significar, em abstrato, infinitas coisas, mas os juristas sabem como esses termos são compreendidos no campo do direito e podem indicar várias situações que exemplificam seu uso.

A identificação de ferramentas "clássicas" do raciocínio jurídico, tais como as regras, os princípios e as analogias, permite que Sunstein afirme que outras formas de raciocínio não são próprias do direito. A crítica mais importante é desferida por ele contra as "teorias gerais", que constituem uma abordagem do direito que decide os casos a partir de um valor unitário que opera em um alto nível de abstração. O utilitarismo e a análise econômica do direito seriam exemplos dessa forma de raciocínio, pois ambos defendem que os resultados das decisões sejam avaliados com base em um único objetivo geral: a maximização da riqueza. Portanto, as teorias gerais operam de modo dedutivo, compreendendo as decisões de casos particulares como consequência lógica de sua aplicação.

Para Sunstein, um dos principais problemas das teorias gerais é que elas não reconhecem a importância dos casos particulares na construção de seus princípios, os quais, muitas vezes, são decisivos para avaliar a correção das teorias. Além disso, qualquer teoria geral pode ser considerada sectária por aqueles que defendem outras teorias, ou considerem que deve-se dar maior peso aos julgamentos de casos particulares ou ainda que acreditem que a moralidade não está baseada em um único valor, mas sim em uma variedade de valores irremediavelmente independentes.

Mais importantes do que as teorias gerais, portanto, são as várias ferramentas de que os juristas dispõem para realizar seu trabalho. Propondo-se a fazer um inventário desses instrumentos, Sunstein alertou que a classificação das disposições legais não pode ser feita em abstrato ou somente com base na leitura da disposição, pois seu conteúdo depende da compreensão e das práticas daqueles que a interpretam. Três tipos de atores participam desse processo: a pessoa ou instituição que editou a disposição jurídica; a pessoa ou instituição que está sujeita a ela; e a pessoa ou instituição encarregada de interpretá-la. O primeiro ator possui um poder limitado sobre essas práticas, pois mesmo que ele emita regras de interpretação, estas também terão que ser interpretadas e não poderão ser exaustivas.

$\mathrm{Na}$ identificação das fontes do raciocínio jurídico, Sunstein apresentou um continuum, em que de um lado se encontra a discricionariedade ilimitada (untrammeled discretion) e no outro extremo, as regras, localizando-se os demais instrumentos (parâmetros, fatores, princípios, diretrizes, analogias) entre os dois polos. A discricionariedade é definida pelo autor como a faculdade de exercer livremente o poder, de acordo com as convicções morais e políticas do agente, sem que haja limites sobre o que ele pode levar em conta para tomar suas decisões. Todos os sistemas jurídicos são obrigados a conviver com algum grau de discricionariedade, mas podem definir quanto dela será atribuído aos agentes. 
Em oposição, as regras se caracterizam por tentar definir, antes do surgimento do caso, a decisão que deve ser tomada. Um sistema de regras existe na medida em que a fixação do conteúdo do direito anteceda sua aplicação e permita especificar, de modo completo ou quase completo, quem tem direito a quê e quais são as consequências jurídicas dos fatos, antes que eles ocorram.

Embora esse objetivo ambicioso não seja plenamente realizável, Sunstein reconhece que muitos casos podem ser resolvidos com base em regras, tais como aquelas que impõem um limite máximo de velocidade, proíbem a entrada de cachorros em restaurantes ou fumar em aviões. Nessas situações, uma avaliação dos fatos, combinada com o entendimento corrente das palavras - e com entendimentos mais substantivos sobre os quais não há divergência -, é suficiente para tomar a decisão, mesmo que possa haver casos difíceis sob as mesmas regras. ${ }^{30}$ Além disso, o autor indica que as regras cumprem o importante papel de atribuir competências no sistema jurídico, tanto na esfera pública quanto na esfera privada.

Vale destacar ainda a análise que Sunstein desenvolve sobre duas concepções de princípios. Na primeira, os princípios são concebidos como justificativas das regras, fornecendo as razões pelas quais elas devem ser aplicadas. Por exemplo, a regra que estabelece o limite de velocidade em 60 milhas por hora justifica-se por razões de segurança. Os princípios que estão por trás das regras também podem ser usados para interpretá-las, o que leva, algumas vezes, ao reconhecimento de exceções: o limite de velocidade pode não ser aplicado a um policial em perseguição a um criminoso. A segunda concepção analisada pelo autor, que utiliza como referência as ideias de Dworkin, estabelece que os princípios fundamentam a decisão de casos. Assim, um tribunal pode solucionar uma controvérsia com base no princípio de que ninguém pode se aprouver de sua própria torpeza ou no princípio da irretroatividade das leis. Para Sunstein, o "peso" desses princípios é variado, uma vez que eles podem ser utilizados tanto como fortes argumentos em favor de uma decisão quanto como meros critérios de desempate na solução de um caso.

O conjunto de instrumentos expostos demonstra, segundo Sunstein, que o raciocínio jurídico possui características particulares, que levam os juristas a fazerem perguntas distintas daquelas que seriam feitas por um filósofo ou um economista. Tal como veremos a seguir, os juristas dispõem de meios próprios para lidar com os conflitos políticos, restringindo os debates de larga escala sobre temas controversos.

\subsection{Precedentes Como ACORdos teóricos incompletos}

Dentre as várias ferramentas do raciocínio jurídico, Sunstein (1996, p. 62-100) destaca as analogias como uma daquelas que mais favorecem a obtenção de acordos teóricos incompletos. ${ }^{31}$ Segundo esse autor, para que os juízes decidam que um caso é igual a outro é necessário utilizar princípios que, na maioria das vezes, operam em nível inferior, o que permite chegar a um acordo sem recorrer a teorias gerais. O estudo do 
raciocínio analógico serve para Sunstein defender a interpretação e aplicação dos precedentes como analogias.

Do ponto de vista do autor, as analogias se colocam em um ponto intermediário entre as formas de pensamento. De um lado, elas não exigem o desenvolvimento de teorias profundas para serem aplicadas; de outro, não é possível raciocinar a partir de um particular em direção a outro particular sem recorrer a um mínimo de abstração, apresentando as razões pelas quais, por exemplo, a decisão do caso A deve ou não valer para o caso B. Por causa dessas características, o raciocínio analógico seria bastante adequado para um sistema jurídico composto de muitos juízes, os quais discordam sobre princípios fundamentais, mas devem considerar a maioria dos casos decididos anteriormente como pontos fixos a partir dos quais eles devem trabalhar.

Sunstein descreve a estrutura básica do raciocínio analógico da seguinte maneira:

1) A possui a característica $X$ ou as características $X, Y$ e Z;

2) B compartilha com A uma, algumas ou todas essas características;

3) A também possui a característica Q;

4) Em razão de A e B compartilharem uma ou algumas características, podemos concluir que B também compartilha a característica Q com A.

De acordo com essa estrutura, o principal problema enfrentado pelo raciocínio analógico decorre do fato de que o caso "objeto" B possui elementos em comum com vários outros casos além de $\mathrm{A}$, o que torna necessário decidir qual desses casos será utilizado como "fonte" da comparação. Consequentemente, o uso de analogias não garante a verdade de suas conclusões, pois a existência de uma ou mesmo de muitas características compartilhadas entre A e B não significa que eles compartilhem todas as demais características. Segundo Sunstein, o máximo que o raciocínio analógico pode nos oferecer, com base nas semelhanças que são conhecidas, é um juízo sobre a probabilidade de que haja outras semelhanças entre os casos.

No campo do direito, as analogias seguem cinco passos:

1) O caso "fonte" A possui as características $\mathrm{X}, \mathrm{Y}$ e Z;

2) O caso “objeto” B possui as características X, Y e A, ou as características X, Y, Z, e A;

3) A é tratado de determinada maneira pelo direito; 
4) Um princípio, criado ou descoberto no processo de reflexão sobre A, B e suas inter-relações, explica porque A é tratado daquela maneira;

5) Em razão das características que compartilha com A, B deve ser tratado da mesma maneira.

Para exemplificar o raciocínio analógico, Sunstein lembra o caso Brandenburg v. Ohio, em que a Suprema Corte decidiu que o discurso de um membro da Ku Klux Klan defendendo o ódio racial somente poderia ser proibido se viesse a incitar a prática iminente de um ato ilícito. Tomando esse caso como fonte, uma marcha do Partido Nazista, que constituiria o caso objeto, também não poderia ser proibida.

Sunstein ressalta que as analogias não possuem caráter dedutivo, pois o princípio que rege ambos os casos não é dado com antecedência e aplicado ao caso objeto, mas surge no decorrer do processo de comparação entre eles. O raciocínio analógico no campo do direito, lembra o autor, tampouco garante bons resultados, uma vez que mesmo casos similares sempre serão diferentes em várias outras dimensões. Portanto, quando os juristas afirmam que não há diferenças relevantes entre A e B, o que eles querem dizer é que nenhuma diferença entre os casos é relevante à luz dos precedentes, que excluem algumas razões que poderiam ser utilizadas para distingui-los; ou, então, que nenhuma diferença pode ser utilizada como base para uma distinção dos casos que faça sentido ou seja baseada em um princípio.

Isso significa que a tarefa central do raciocínio analógico é decidir quais são as diferenças e semelhanças relevantes nos casos em análise, o que torna necessário trabalhar com argumentos de cunho substantivo. Para Sunstein, o bom desenvolvimento das analogias no direito deve observar quatro elementos: (1) os julgamentos sobre casos específicos devem ser coerentes uns com os outros, baseando-se em princípios que harmonizem os diferentes resultados; (2) o foco do raciocínio analógico devem ser as particularidades, o que significa que seus princípios são desenvolvidos a partir de casos concretos e fazem constante referência a eles; (3) o raciocínio analógico não requer uma teoria de larga escala para justificar seus resultados; e (4) os princípios produzidos pelo raciocínio analógico operam em um nível intermediário ou inferior de abstração. Segundo esse autor, esse tipo de analogia constitui, ao lado da interpretação das regras, o raciocínio mais utilizado pelos juristas.

Estabelecidos esses parâmetros, Sunstein pode aprofundar de que maneira o raciocínio analógico lida com os precedentes. Em primeiro lugar, o autor distingue três espécies de julgamentos: (1) os precedentes vinculantes, que não podem ser revogados (overruled) pelos juízes, tais como as decisões da Suprema Corte norte-americana em relação aos tribunais inferiores; (2) os precedentes não vinculantes, que podem ser revogados em circunstâncias excepcionais, posição adotada pela Suprema Corte em relação a seus próprios precedentes; e (3) os julgamentos hipotéticos que, embora não 
constituam precedentes, são tão óbvios que assumem o mesmo status, por exemplo, a ideia de que o Estado não pode prender os cristãos em razão da sua fé ou não pode obrigar somente os hispânicos a doarem sangue para outras pessoas. Apesar de suas diferenças, em todas essas situações é necessário identificar a holding do caso, isto é, a fundamentação mínima da decisão que deverá ser aplicada aos casos posteriores. Para Sunstein, essa fundamentação pode ser considerada muito ampla ou muito restrita à medida que novos casos vão surgindo, o que demonstra que não se pode antecipar completamente o conjunto de situações que a holding abrange. Portanto, a identificação da holding não se baseia na descoberta de algo que já se encontra no precedente, mas sim em uma construção feita pelos tribunais que a ele se vinculam.

Essa construção pode fazer com que o precedente funcione tanto como uma regra, quanto como uma analogia. Na primeira hipótese, o precedente se aplica aos casos idênticos a ele, isto é, a casos obviamente similares que não possuem diferenças relevantes. Já como analogia, o precedente se aplica a casos em que, embora haja diferenças, seu princípio é relevante para solucioná-los. Sunstein reconhece que não é fácil distinguir quando um precedente atua como regra e quando ele atua como analogia, pois essa conclusão só pode ser obtida mediante a análise do caso posterior e depende de que certos entendimentos sejam compartilhados pela comunidade.

Quando se diz que o precedente é uma regra, isto significa que ele é tão semelhante ao caso em questão que ninguém colocará em dúvida sua aplicação. Mas, quando o precedente é concebido como analogia, isso implica o reconhecimento de que há diferenças relevantes entre os casos e a aplicação do precedente requer alguma justificação. Como os casos nunca são completamente idênticos, é o tribunal posterior que decidirá quais são as diferenças e semelhanças relevantes, de acordo com a importância que for atribuída às suas várias características.

Para Sunstein, o tratamento dos precedentes como analogias é uma alternativa superior tanto às regras quanto às teorias gerais. Em primeiro lugar, o raciocínio analógico exige um compromisso com a consistência e com o direito a igual tratamento: a parte do caso A não pode ser tratada de modo distinto da parte do caso $\mathrm{B}$, a menos que haja uma diferença relevante entre eles. Em segundo lugar, as analogias podem ser uma fonte de princípios e de políticas, desde que os juízes saibam encontrá-los nos precedentes. Em terceiro lugar, o respeito aos precedentes como analogias ajuda a evitar que os juízes utilizem teorias confusas ou sectárias. Em quarto lugar, o raciocínio analógico baseado em precedentes promove os valores da previsibilidade e da proteção das expectativas. Em quinto lugar, o raciocínio analógico poupa uma grande quantidade de tempo, pois a observância dos precedentes desobriga os juízes de recriarem a cada momento os fundamentos do direito. Por último, precedentes e analogias facilitam o surgimento de acordos entre juízes que, embora divirjam sobre vários assuntos, reconhecem como válidas certas decisões anteriores, o que torna possível estabelecer um diálogo entre eles. 
Particularmente no campo do direito constitucional, o uso do raciocínio analógico com base em precedentes também contribui para legitimar o exercício do judicial review, pois leva a utilizar decisões anteriores que sobreviveram ao tempo e contam com um alto grau de aprovação popular. Tais decisões devem funcionar como pontos fixos para a investigação de casos futuros, evitando que os juízes se envolvam com justificações filosóficas.

\section{Precedentes como Princípios: DWorkin e o Romance em CAdeia}

No artigo $\mathrm{O}$ modelo de regras, que deu início à construção de uma teoria do direito oposta ao positivismo, Dworkin (2002, cap. 2) propôs uma distinção que se tornou célebre: entre princípios, que são aplicados de acordo com seu peso, e regras, que são aplicadas de maneira tudo ou nada. Embora esse autor já indicasse que essa distinção não era absoluta, pois a aplicação de uma regra poderia depender de argumentos de princípios, devemos destacar que sua teoria evoluiu da "fenomenologia da jurisdição" para compreender o direito como uma prática social argumentativa fundada em princípios de moralidade política (DWORKIN, 1999). Assim, Dworkin defende que as proposições jurídicas, isto é, o conjunto de afirmações sobre o que o direito proíbe ou permite, somente são verdadeiras se estiverem de acordo com os princípios de justiça, equidade e devido processo legal, que oferecem a melhor interpretação da prática jurídica da comunidade política. Ao contrário das teorias dualistas, que compreendem os princípios como um "tipo de norma” e distinguem o momento de aplicação das regras e o momento da aplicação dos princípios, que se reserva aos "casos difíceis", o autor afirma que a correção de qualquer decisão judicial depende da correta interpretação dos princípios pertinentes ao caso. ${ }^{32}$

Por essa razão, Dworkin (1999, p. 422-424) refuta a ideia de que sua teoria seja aplicável apenas aos casos difíceis, o que dispensaria o juiz de levar em conta questões de moralidade para decidir, por exemplo, se uma pessoa pode dirigir legalmente acima do limite de velocidade ou se deve pagar sua conta de telefone. Para esse autor, além de ser difícil estabelecer um critério para distinguir casos fáceis e difíceis, mesmo naqueles em que a resposta às questões de princípio parece óbvia há uma teoria pressuposta que justifica a decisão, em que a ampla aceitação significa que não é necessário desenvolver completamente os argumentos a seu favor. Contudo, alguém que interprete de modo muito distinto os princípios da comunidade política pode trazer argumentos que demonstrem que a questão não é tão simples, o que explica por que casos fáceis tornam-se difíceis com o passar do tempo.

\section{I INTEGRIDADE E COMUNIDADE DE PRINCÍPIOS}

Para desenvolver sua teoria, Dworkin (1999, p. 116) parte de um conceito segundo o qual o direito é formado pelo conjunto de direitos e responsabilidades que fluem 
de decisões políticas passadas e justificam o uso da coerção pelo Estado. Na busca dos princípios que podem oferecer a melhor justificativa para essa conexão entre direito e coerção, Dworkin (1999, p. 213-231) propõe que a integridade seja reconhecida como um ideal político independente, distinto tanto da equidade, que lida com os critérios de organização do processo político, quanto da justiça, que trata dos resultados do processo político. Para o autor, essa distinção é importante porque a integridade pode resolver os conflitos entre justiça e equidade, que aparecem quando instituições equitativas produzem decisões injustas e instituições não equitativas produzem decisões justas.

A integridade exige que as instituições estatais atuem sempre de modo coerente com os princípios de moralidade política que justificam suas ações, o que significa que o Estado deve fundamentar suas decisões em uma interpretação desses princípios que reconheça seu devido peso e importância em cada caso. Dessa maneira, alega Dworkin, a integridade pode oferecer uma concepção do direito que legitima o uso do poder coercitivo e o reconhecimento de obrigações políticas de parte dos cidadãos.

Na construção desse argumento, Dworkin (1999, p. 237-259) formula o conceito de obrigações associativas ou comunitárias, que derivam do pertencimento das pessoas a determinados grupos definidos pela prática social. Ao contrário de outras obrigações, que são escolhidas ou expressamente aceitas pelos indivíduos, as obrigações associativas são definidas por meio de uma atitude interpretativa de caráter construtivo: os participantes buscam os propósitos da prática social a que pertencem e produzem argumentos em torno das obrigações que devem caracterizá-la. Para esse autor, o caráter associativo das obrigações baseia-se no cumprimento de quatro condições, todas elas baseadas na reciprocidade: em primeiro lugar, os membros devem considerar as obrigações do grupo como especiais, pertencentes àquele grupo, e não como deveres gerais em relação a pessoas que se encontram fora dele. Em segundo lugar, as responsabilidades que derivam dessas obrigações são pessoais, no sentido de que devem se dirigir a cada membro e não apenas ao grupo como um todo. Terceiro, as responsabilidades particulares do grupo fluem de uma responsabilidade mais geral que cada membro possui com o bem-estar dos demais membros do grupo, embora o nível e o escopo do cuidado variem de acordo com o tipo de associação. Quarto, as práticas do grupo demonstram igual consideração por todos os seus membros.

Com base nas características das obrigações associativas, Dworkin passa a distinguir três modelos de comunidade política, em que cada um deles descreve as atitudes que seus membros tomariam uns em relação aos outros, de modo consciente, caso sustentassem a visão de comunidade que o modelo expressa. O primeiro modelo pressupõe que os membros de uma comunidade tratam sua associação apenas como um acidente histórico ou geográfico e, portanto, não como uma verdadeira comunidade associativa. Nesse tipo de comunidade "de fato", a cooperação entre seus membros só 
é possível quando traz vantagens para ambas as partes, assumindo um caráter estratégico de obtenção de meios para realização de fins.

O segundo modelo é chamado por Dworkin de comunidade de regras. Os membros que compreendem a comunidade admitem que possuem um compromisso geral de obedecer às regras que foram estabelecidas na forma reconhecida como válida pela comunidade. Por exemplo, as regras negociadas pelas partes em um contrato são cumpridas por que elas criam uma obrigação, e não apenas por razões estratégicas. Assim, as regras representam um compromisso entre interesses antagônicos, no qual cada lado tenta obter o máximo possível, dentro dos limites do que foi expressamente acordado entre as partes, mas não implicam um compromisso com princípios que possam ensejar obrigações futuras. Nessa concepção, cada membro da comunidade tenta realizar suas concepções de justiça e equidade por meio de negociações e compromissos, cujas regras devem ser respeitadas até um novo acordo venha a ser firmado.

O terceiro modelo é o da comunidade de princípios, segundo o qual a comunidade política requer um entendimento compartilhado entre seus membros de que ela é regida por princípios comuns e não apenas por regras forjadas em acordos políticos. Nessa concepção, os membros da comunidade admitem que seus direitos e deveres não se esgotam nas decisões particulares tomadas por suas instituições, mas dependem do esquema de princípios pressuposto por essas decisões, o que implica reconhecer que há direitos e deveres que fluem desse esquema, mesmo que nunca tenham sido formalmente identificados ou declarados. O modelo da comunidade de princípios não implica que cada membro esteja de acordo com todos os princípios que fazem parte do esquema, mas exige que as obrigações que decorrem da adoção desses princípios pela comunidade sejam aceitas por todos.

Para Dworkin, somente o último modelo satisfaz as exigências de uma comunidade fundada em obrigações associativas. O primeiro modelo não atende nem mesmo à primeira condição referente a essas obrigações, pois não reconhece nenhuma atitude especial de consideração dos membros da comunidade uns com os outros, uma vez que as pessoas que a integram não possuem nenhum interesse senão a realização de seus próprios objetivos egoístas. O modelo de regras atende à primeira e à segunda condições, uma vez que os membros da comunidade demonstram uma consideração especial em relação a todos os demais, no sentido de que cada pessoa tem o direito de receber os benefícios de quaisquer decisões políticas que forem tomadas de acordo com os arranjos políticos em vigor. No entanto, esse modelo não atende à terceira condição, pois a consideração que ele demonstra pelos demais é muito atenuada para ser autêntica. As pessoas na comunidade de regras têm liberdade para agir de modo quase tão egoísta quanto as pessoas na comunidade de fato, usando as instituições políticas para buscar seus próprios interesses e ideais. Assim, embora seus membros reconheçam que as decisões tomadas pelas instituições políticas geram uma obrigação 
de garantir seu cumprimento para todos que dela se beneficiam, esse compromisso não evidencia uma preocupação com o bem-estar dos outros, nem impede que as pessoas atuem durante o processo legislativo sem levar em conta os ônus que seus benefícios podem trazer aos demais.

O único modelo que preenche todas as condições em uma sociedade moralmente pluralista, em que as pessoas divergem sobre os critérios de justiça e equidade, é o da comunidade de princípios. Nesse modelo, as responsabilidades da cidadania são consideradas especiais, no sentido de que cada cidadão respeita os princípios de justiça e equidade incorporados nos arranjos políticos de sua comunidade, mesmo que eles não correspondam àqueles que ele considera os melhores de um ponto de vista utópico. Essas responsabilidades são também pessoais, pois nenhum membro da comunidade pode ser excluído do processo político, e a preocupação com o bemestar dos demais demanda o sacrifício de interesses individuais em todos os momentos da vida política, seja na atividade legislativa, no exercício da jurisdição, ou na execução das leis. Além disso, o modelo assume que cada membro da comunidade é tão valioso quanto os demais e deve ser tratado com igual consideração.

O compromisso de desenvolver e interpretar o direito de modo principialista, assumido por uma comunidade de princípios, faz com que seus membros aceitem a integridade como um ideal político distinto, mesmo que divirjam sobre questões de moralidade política. Sobre essa base, uma sociedade política ampla e diversa pode se tornar uma autêntica comunidade associativa, reivindicando legitimidade no exercício do poder.

Para Dworkin, mesmo que esses modelos tenham uma característica ideal, pois a maioria das pessoas não aceita as atitudes de nenhum deles, eles nos ajudam a interpretar as atitudes expressas em nossas práticas políticas Se podemos compreender as nossas práticas como apropriadas para o modelo de princípios, podemos apoiar a legitimidade de nossas instituições e as obrigações políticas que elas assumem, como uma questão de fraternidade e, assim, podemos buscar aprimorá-las nessa direção.

Por essa razão, Dworkin (1999, p. 263-264) destaca que a integridade não deve ser confundida com a consistência (consistency), que significa simplesmente tratar igualmente os casos iguais. Para o autor, a consistência exige que uma instituição repita rigorosamente suas decisões políticas passadas, enquanto a integridade requer que os padrões normativos (standards) da comunidade sejam constantemente elaborados e compreendidos de maneira a expressar um único esquema coerente de relação entre justiça e equidade. Isso implica que uma instituição que aceite a integridade terá, algumas vezes, que se afastar de uma linha estreita de decisões passadas em busca de coerência com os princípios mais fundamentais desse esquema, o que encoraja o juiz a reconhecer novos direitos quando se demonstre que uma parte dessas decisões não é compatível com os princípios que justificam o direito como um todo. 


\subsection{Precedentes no romance em Cadeia}

Para expor de que modo a integridade opera no campo da jurisdição, Dworkin (1999, p. 271-308) utiliza a metáfora do romance em cadeia, segundo a qual um grupo de autores escreve um romance em que cada um interpreta os capítulos anteriores para escrever um novo capítulo, que, então, será adicionado ao material que o próximo romancista receber. Cada autor deve escrever seu capítulo de modo a tornar o romance o melhor que ele pode ser, sem perder sua unidade.

No desenvolvimento de seu trabalho, os autores terão que fazer uma série de julgamentos para identificar os vários sentidos da obra e o que nela deve ter continuidade. Dworkin distingue os julgamentos que devem ser realizados em duas dimensões. A primeira delas é a dimensão da adequação, que exige que o autor elabore interpretações que estejam de acordo com o que foi escrito antes. Isso não significa que a interpretação tenha que se ajustar a todas as partes do texto, mas sim que ela deve dar conta de seus principais aspectos estruturais. Sendo possíveis várias interpretações adequadas ao conjunto do texto, o autor terá que escolher qual delas vai tornar o romance melhor, considerados todos os seus elementos. Essa segunda dimensão, embora tenha caráter mais substantivo, também levará em conta os aspectos de índole formal, pois uma interpretação que se ajuste muito mais que outra deve ser preferida, mesmo que sua rival possa indicar, para o autor, um desenvolvimento mais interessante para o romance.

Na elaboração do romance em cadeia, é fundamental discernir se os julgamentos feitos por seus participantes são livres ou limitados. Em primeiro lugar, Dworkin destaca que todas as dimensões da interpretação são dependentes das conviç̧ões estéticas dos intérpretes e estão sujeitas a controvérsias. Tanto a interpretação sobre quais leituras se ajustam ao texto, quanto à interpretação sobre qual dessas leituras torna o romance melhor, se inserem em um esquema geral de crenças e atitudes dos autores. Mesmo assim, essas crenças impõem limites genuínos à interpretação, tal como ocorre quando experimentamos um conflito entre nossas convicções, o qual faz com que uma destas nos impeça de agir conforme a outra, ou conforme o que várias pessoas julgariam ser acertado.

No entanto, Dworkin reconhece que os limites impostos pela exigência de adequação podem não estar suficientemente separados das convicções substantivas do intérprete, de maneira a controlá-las. Nesse caso, sempre que o intérprete preferir uma determinada leitura do texto por razões substantivas, suas conviç̧ões formais automaticamente serão adaptadas para endossá-la como a leitura correta, mesmo que o intérprete acredite que está sendo fiel ao que foi escrito antes dele. Uma interpretação genuína, portanto, requer que as convicções do intérprete realmente controlem umas às outras, o que depende de que o romance seja analisado como um todo.

Trazendo a metáfora do romance em cadeia para o exercício da jurisdição, notase que a integridade trata o direito como um conjunto coerente de princípios, sejam 
eles explícitos ou implícitos, orientando o juiz a se perguntar sobre a adequação e justificativa de sua decisão em face desses princípios. Ao mesmo tempo em que deve se ajustar aos precedentes, a decisão de um caso concreto também deve oferecer a melhor justificativa para o uso do poder coercitivo do Estado, a fim de continuar desenvolvendo a história do direito da comunidade de modo compatível com os princípios que a regem. Assim, enquanto na dimensão formal da interpretação o juiz deve investigar se a decisão corresponde àquelas tomadas sobre casos similares, na dimensão substantiva ele deve buscar quais são os princípios de justiça e equidade que podem justificar a decisão. Essas duas dimensões devem sempre caminhar juntas, de maneira que o juiz possa verificar se uma interpretação que se ajusta também se justifica, e vice-versa.

A concepção da integridade, portanto, nos convida a interpretar os precedentes buscando os princípios morais que os fundamentam, a fim de decidir se eles devem ou não se aplicar ao caso atual. Ela não exige que as decisões passadas sejam repetidas, sob o argumento de que casos iguais devem ser tratados igualmente. Se um precedente não se fundamenta em princípios, ele não deve ser aplicado, do mesmo modo que são os princípios que nos permitem identificar se as diferenças entre os casos devem ser consideradas relevantes ou não. A integridade oferece razões para que o precedente seja mantido se não houver nenhum princípio que venha a ser violado quando de sua aplicação ao caso, da mesma forma que ela justifica a distinção entre os casos e a não aplicação do precedente em razão de um princípio cuja aplicação ao caso atual seja mais coerente com o conjunto do sistema jurídico do que a aplicação do princípio pressuposto nos casos anteriores.

A interpretação dos precedentes regida por princípios será tanto mais aperfeiçoada quanto maior for o número de casos que o juiz analisar para tomar sua decisão, a fim de que possa identificar o peso relativo que os diferentes princípios possuem no sistema jurídico. Partindo dos casos imediatamente relacionados ao caso atual para casos no mesmo ramo do direito - ou mesmo além, se for necessário para aferir a coerência -, o juiz poderá abarcar um conjunto amplo de decisões anteriores que lhe permitirá decidir qual princípio, dentre aqueles que concorrem para a solução do caso, mais se ajusta a esse conjunto e oferece sua melhor justificativa.

Dworkin (1999, p. 148-165) critica ainda a concepção de precedente defendida pelo convencionalismo. Nesse passo argumentativo, o autor define a extensão de uma convenção jurídica, tal como a lei ou o precedente, como o conjunto de juízos ou decisões impostos por ela. Tal extensão possui uma dimensão explícita, que é formada pelo conjunto de proposições que a ampla maioria das pessoas aceita como parte da convenção, e uma dimensão implícita, formada pelo conjunto de proposições que decorrem da melhor interpretação da convenção, façam ou não parte de sua extensão explícita. ${ }^{33}$

Segundo Dworkin, o convencionalismo defende que os juízes observem apenas a extensão explícita dos precedentes, o que significa que eles decidem de modo 
discricionário quando essa extensão não é suficientemente densa para solucionar o caso. Além de observar que o convencionalismo tem muito pouco a dizer na maioria dos casos que chegam aos tribunais e atraem a atenção da opinião pública, Dworkin afirma que a integridade, ao contrário, impõe aos juízes buscar os princípios que justificam os precedentes a fim de decidir se as pessoas possuem direitos além daqueles já reconhecidos em sua extensão explícita.

\section{Argumentos}

As três concepções apresentadas neste artigo demonstram que há diferentes maneiras de interpretar os precedentes, o que significa que seu caráter vinculante não exime o juiz de analisar as várias possibilidades que se apresentam para decidir o caso de acordo com eles. Com efeito, todas as concepções partem do reconhecimento da existência de precedentes obrigatórios, típicos do sistema de common law, contudo, diante de um caso concreto, cada teoria pode conduzir a uma decisão distinta com base nos mesmos precedentes. Para que essa escolha não seja feita de modo arbitrário, é necessário apresentar as razões pelas quais uma concepção é mais adequada que as outras. Os argumentos em favor de cada uma das teorias são apresentados pelos próprios autores, e passarão a ser analisados com o objetivo de também identificar qual concepção melhor justifica as decisões tomadas pelo STF discutidas no início deste texto.

Ao apresentar os argumentos em defesa de um modelo de decisão baseado em regras, Schauer (1991, p. 135-166) reconhece que o quadro desenhado em sua obra não é muito atrativo. Afinal, as regras fazem com que os agentes decidam de acordo com elas quando isso produz resultados divergentes ou inferiores àqueles que seriam produzidos pela aplicação direta de sua justificativa. Isso significa que aceitar o modelo de regras requer tolerância com um certo número de resultados errados.

$\mathrm{Na}$ busca de argumentos que demonstrem a superioridade das regras, Schauer exclui, de início, o argumento da equidade (fairness), segundo o qual decidir com base em regras gerais é parte do que equidade e justiça significam, tal como exemplifica a máxima "tratar igualmente os casos iguais". Tendo em vista que as regras são generalizações que ignoram diferenças que podem ser relevantes e consideram outras que podem ser irrelevantes, de acordo com as circunstâncias, casos diferentes serão tratados como semelhantes e vice-versa. Portanto, não é o modelo baseado em regras que atende a esses ideais de justiça, mas sim o particularismo, que reconhece as diferenças e semelhanças relevantes e desenvolve todas as distinções que alguma justificativa substantiva indica que devem ser feitas. ${ }^{34}$

Schauer também critica os conhecidos argumentos da confiança e da eficiência. De acordo com o primeiro, agentes que seguem as regras, mesmo quando outros resultados parecem ser preferíveis, possibilitam àqueles que serão afetados por elas prever 
as decisões que serão tomadas e planejar melhor suas atividades. Para o segundo, quando um agente decide de acordo com regras, ele se encontra parcialmente livre da responsabilidade de analisar cada característica relevante do caso, concentrando sua atenção somente na presença ou ausência de alguns fatores. O resultado seria uma maior eficiência do processo de tomada de decisão, pois os agentes estariam livres para cumprir outras responsabilidades e não haveria duplicação de esforços dentro do mesmo ambiente decisório.

Em ambos os casos, Schauer indica que os custos das decisões baseadas em regras podem eliminar suas vantagens. No que se refere ao argumento da confiança, seu valor depende da medida em que um ambiente decisório tolera resultados sub-ótimos, a fim de que os afetados pelas decisões sejam capazes de planejar certos aspectos de sua vida. Essa tolerância tende a diminuir quanto mais relevantes forem os fatos suprimidos, ou menos relevantes, os fatos destacados no predicado da regra, e também quanto mais a decisão estiver abaixo da melhor decisão que seria tomada se todos os fatores fossem levados em conta. ${ }^{35}$ Assim, decisões erradas podem acabar tornando mais difícil confiar em quem as toma. Quanto à busca de eficiência, Schauer considera que seu valor depende das outras destinações que podem ser dadas aos recursos decisórios economizados, e se for um uso valioso pode tolerar um certo número de resultados sub-ótimos. Portanto, quando os recursos decisórios não são escassos ou há poucas alternativas atraentes para seu uso, é menos provável que os benefícios da eficiência tenham mais peso que os custos necessariamente envolvidos em qualquer processo de tomada de decisão que não esteja apto para buscar o resultado ótimo em cada situação.

A reflexão feita por Schauer sobre os custos das decisões sub-ótimas demonstra que a validade dos argumentos da confiança e da eficiência depende do contexto em que as regras são aplicadas. Para identificar esse contexto em que as regras podem ser defendidas, o autor parte do reconhecimento de que os agentes também cometem erros quando têm competência para perquirir todos os fatores que poderiam levar à melhor decisão de um caso particular. Tal contraponto indica que, muitas vezes, os agentes empregam sua liberdade de modo inadequado, utilizando fatores que poderiam produzir o melhor resultado para, ao contrário, produzir algo inferior a ele.

Assim, quanto maior o número de fatores levados em conta em um processo de decisão, maior será a probabilidade de confusões ou equívocos cometidos pelos agentes, seja em razão de sua falta de treinamento para lidar com essas questões, seja em razão dos preconceitos que o agente pode ter em relação a certos aspectos do caso.

Um policial, por exemplo, se não dispuser de regras para conduzir o interrogatório de um acusado, pode não dar a devida importância a seus direitos. Por essa razão, o desenho de um ambiente decisório deve considerar não apenas a possibilidade de haver erros provocados pela subinclusividade ou pela sobreinclusividade das regras, mas também a possibilidade de que erros sejam cometidos quando os 
agentes têm competência para aplicar diretamente as justificativas aos casos que eles devem decidir.

Como os dois tipos de erro estão inter-relacionados, pois a tentativa de reduzir a incidência de um aumenta a probabilidade do outro, o desenho de qualquer processo de tomada de decisão envolve uma avaliação comparativa da frequência e das consequências desses diferentes erros.

Para Schauer, quando os agentes são confiáveis e as decisões a serem tomadas por eles incluem uma alta proporção de situações comparativamente únicas, com sérias consequências, caso sejam decididas erroneamente, é provável que o modelo baseado em regras seja recusado ou moderado. Contudo, se houver razão para desconfiar de um conjunto de agentes em relação a certos tipos de determinações, e o conjunto de decisões a ser tomado for comparativamente previsível, os erros das regras tendem a ser menos relevantes do que os erros dos agentes, tornando mais forte o argumento em favor das regras.

Uma vez reconhecidos os dois tipos de erro, e que o processo de decisão baseado em regras busca minimizar a incidência do erro do agente, mesmo sob o preço de ampliar a incidência do erro baseado na regra, Schauer afirma que um argumento persuasivo em favor das regras é o argumento da aversão ao risco. Considerando que qualquer processo de decisão produzirá erros, a adoção do modelo baseado em regras se apoia em uma avaliação de que os erros que podem ser cometidos por agentes equivocados - seja por preconceito, ignorância, incompetência ou simplesmente por confusão -, são mais sérios ou mais prováveis do que os erros baseados em regras que advêm de uma limitação interna para alcançar a melhor decisão em todos os casos. ${ }^{36}$

Isso demonstra que todos esses argumentos têm como premissa a relutância de que certos tipos de agentes possam tomar certos tipos de decisão, defendendo que não lhes seja atribuída competência (decisional jurisdiction) para apreciar determinados fatos ou razões no processo de tomada de decisão. No caso dos argumentos da confiança e da eficiência, a retirada de competência pode estar baseada simplesmente no desejo de limitar o âmbito das variações permitidas na decisão ou evitar a perda de recursos decisórios. No caso do argumento da aversão ao risco, essa retirada se baseia na desconfiança de que os tomadores de decisão produzirão decisões erradas se puderem considerar certos fatos ou razões.

Em qualquer caso, as regras são compreendidas como meios para determinar quem deve levar em consideração o quê, funcionando, portanto, como instrumentos de alocação de poder. Um agente que não se encontra limitado por regras tem competência para considerar todos os aspectos envolvidos, enquanto o agente que se encontra limitado perde, ao menos, uma parte dessa competência.

Seguindo a terminologia adotada por Schauer, podemos dizer que as decisões do STF analisadas neste artigo preferiram não assumir os custos da "sub-otimalidade". Ao se confrontarem com uma "experiência recalcitrante", os Ministros optaram por 
refletir sobre a justificativa da súmula, tomando a decisão que lhes pareceu melhor diante das circunstâncias do caso.

Deve-se reconhecer que a teoria de Schauer não exige que os juízes sempre apliquem as regras, assumindo que haverá casos em que elas serão afastadas em favor de outras razões que tenham mais peso naquela situação. Dessa forma, os acórdãos relatados poderiam ser vistos como exceções que não invalidam as vantagens da utilização, pelo STF, de um processo de decisão baseado em regras, em que as generalizações contidas nas súmulas seriam aplicadas mesmo quando entrassem em conflito com suas justificativas.

A análise mais detida dos julgados, contudo, mostra as dificuldades de aplicar os argumentos defendidos por Schauer. Para ele, o predicado factual da regra permite limitar o conjunto de fatores que será levado em conta na decisão, o que se baseia na ideia de que as palavras nele contidas possuem um sentido acontextual ou literal, que independe das circunstâncias em que elas são utilizadas e pode ser compreendido por todos aqueles que dominam uma determinada linguagem.

Se observarmos as três súmulas citadas, veremos que as generalizações representadas por expressões como "aposentadoria”, "processo administrativo disciplinar” e "parente" nos permitem identificar casos aos quais a súmula se aplica sem que seja necessário invocar, à primeira vista, sua justificativa. Assim, a linguagem jurídica enquadra o benefício previdenciário recebido por um servidor do IBGE, o procedimento instaurado pela autoridade penitenciária, e a relação de parentesco entre irmãos, como casos que exemplificam aquelas generalizações.

Porém, mesmo em situações que parecem responder às exigências do modelo de Schauer, o STF, quando provocado, não deixa de analisar outros fatores relevantes para a decisão do caso, a fim de decidir se a súmula se aplica ou não a ele. Ao contrário do que defende o autor, para quem uma experiência recalcitrante não deve influenciar a aplicação da regra, ${ }^{37}$ seu surgimento tende a levar o Tribunal a rever a justificativa da súmula e de seus precedentes e, somente após essa análise, decidir sobre a adequação de sua generalização ao caso.

Compreendendo que a justificativa das súmulas vinculantes n. 3 e n. 5 é a ausência de direitos do interessado, tendo em vista as características dos atos de registro feitos pelo TCU e do processo administrativo disciplinar, e a justificativa da SV n. 13 é a defesa da moralidade administrativa, percebemos que, em todas essas situações, o STF concluiu, nos termos de Schauer, que estava diante de casos de sobreinclusão que não autorizavam a aplicação da súmula, pois isso acarretaria violação de direitos ou não teria como efeito a proteção da moralidade administrativa.

O desenvolvimento da jurisprudência do STF sobre as súmulas vinculantes também demonstra que o argumento da aversão ao risco não possui força suficiente para justificar o tratamento dos precedentes como regras, de acordo com o modelo de decisão proposto por Schauer. Como vimos, esse argumento se baseia em uma avaliação 
negativa dos erros que podem ser cometidos pelos agentes se lhes for permitido levar em consideração todas as circunstâncias do caso, o que impõe a diminuição de sua competência. Sendo questionável a aplicação desse argumento para as instâncias inferiores do Poder Judiciário, é ainda mais difícil justificar que o STF deva tratar as generalizações das súmulas como enraizadas em razão dos erros que o Tribunal possa cometer na interpretação de seus precedentes.

É importante lembrar que o próprio STF detém, constitucionalmente, o poder de cancelar suas súmulas, além de ser a última instância que decidirá as dúvidas que surjam quanto à sua aplicação. Embora não possamos desconsiderar a hipótese de que decisões erradas venham a ser tomadas pelo STF, a posição institucional do Tribunal lhe permite aproveitar-se das discussões ocorridas nas instâncias inferiores do judiciário para fazer um exame cuidadoso das circunstâncias do caso e dos argumentos apresentados a favor e contra a aplicação da súmula, o que constitui o melhor remédio para evitar que esses erros sejam cometidos. Por meio da ampliação da análise dos elementos envolvidos no caso, o STF pode tomar decisões ainda mais bem fundamentadas, contribuindo para esclarecer, perante a comunidade jurídica, o conteúdo da súmula, evitando sua aplicação indevida, que poderia resultar da interpretação dos precedentes como regras. ${ }^{38}$

Além disso, o próprio Schauer reconhece que a regra não deve ser aplicada se levar a uma grande injustiça ou a resultados absurdos, pois sua versão do positivismo se baseia na força presumida das regras, o que significa que elas podem ser afastadas no processo de decisão, caso sejam apresentadas razões particularmente exigentes para não aplicá-la.

Como aponta Sunstein (1996, p. 124-128), o fato de uma regra sempre comportar exceções faz com que a decisão do juiz sobre sua aplicação a um determinado caso envolva um juízo de cunho moral e político sobre quais semelhanças e diferenças são relevantes. Assim, se Schauer admite que a regra não seja aplicada a casos excepcionais, será virtualmente possível em todos os casos questionar se estamos diante de uma situação absurda, o que significa que o conteúdo do direito volta a depender de uma análise de princípios feita no momento da aplicação da regra.

Um tipo de situação que exige do julgador um cuidado redobrado na análise das circunstâncias e dos princípios envolvidos no caso ocorre quando se está diante de direitos fundamentais. Os deveres que eles impõem a todos os poderes públicos obrigam o juiz a deixar de aplicar uma regra que incorra em violação desses direitos. Isso é o que verificamos nos dois primeiros casos tratados, em que a aplicação da súmula não respeitaria os direitos fundamentais à segurança jurídica e à liberdade de locomoção, o que representou um argumento decisivo para que o STF julgasse que a situação do servidor aposentado há mais de cinco anos e do preso condenado em processo administrativo disciplinar não seriam alcançadas pelas súmulas. Verifica-se, assim, que os custos da violação de um direito fundamental não justificam a tomada de uma decisão sub-ótima. 
Isso nos leva a buscar, nas demais teorias do precedente, os possíveis fundamentos das decisões do STF que deixam de aplicar as súmulas vinculantes. Ao contrário do modelo proposto por Schauer, as teorias de Sunstein e Dworkin reconhecem que a aplicação do precedente requer que o juiz formule as razões que justifiquem essa aplicação. Assim, a decisão sobre a similitude ou diferença de um caso em relação a outro deve sempre estar fundamentada em princípios de cunho substantivo.

As diferenças entre Sunstein e Dworkin aparecem, contudo, nos limites que o primeiro impõe à análise que deve ser feita pelos juízes. ${ }^{39}$ Para o primeiro autor, os acordos teóricos incompletos são fundamentados em princípios que prescindem do desenvolvimento de teorias gerais. Embora reconheça que não é fácil distinguir entre uma teoria de nível superior e outra que opera em um nível intermediário ou inferior, ${ }^{40}$ Sunstein (1996, p. 35-44) afirma que os princípios que normalmente compõem a "doutrina” jurídica não derivam de nenhuma teoria ampla sobre o bem ou sobre o justo, mantendo relações ambíguas com essas teorias e sendo compatíveis com mais de uma delas. Assim, mesmo que as pessoas divirjam sobre alguma proposição de nível relativamente alto, elas podem chegar a um acordo se reduzirem o nível de abstração, concordando sobre a decisão do caso particular. Uma marcha neonazista, por exemplo, pode ser considerada lícita pelos juízes mesmo que eles não compartilhem uma teoria geral da liberdade de expressão.

Em sua defesa dos acordos teóricos incompletos, ${ }^{41}$ Sunstein argumenta que as instituições judiciais, que devem justificar publicamente suas decisões em um ambiente de grandes controvérsias, precisam lançar mão desses acordos para resolver casos em que as pessoas discordam sobre princípios gerais. Assim, os acordos promoveriam várias virtudes: (1) permitiriam a redução do custo político das divergências, uma vez que a derrota em um caso não impediria que uma parte da sociedade pudesse continuar defendendo suas convicções mais profundas em outros; (2) facilitariam a evolução moral da sociedade, impedindo que a cultura jurídica se torne muito rígida e dificulte a absorção das mudanças sociais pelo direito; (3) tenderiam a aperfeiçoar o uso do tempo e da capacidade em contextos nos quais esses recursos são limitados; e (4) promoveriam o respeito aos precedentes, que seriam tratados como pontos fixos que somente podem ser revistos em circunstâncias excepcionais, mesmo que seus fundamentos sejam incompatíveis entre si.

Ao tratar a questão do ponto de vista do direito constitucional, Sunstein (1996, p. 46) reconhece que, no exercício de sua função de intérprete da Constituição, o judiciário pode invocar princípios relativamente amplos, vistos como parte essencial da Constituição, tal como foram democraticamente ratificados. Porém, mesmo nesse campo, o autor aponta que os argumentos judiciais costumam se basear em princípios de nível inferior, excetuando as raras ocasiões em que um raciocínio mais ambicioso torna-se necessário para resolver um caso ou quando os argumentos em 
favor de uma teoria completa são tão fortes que um conjunto de juízes acaba convergindo em torno dela. ${ }^{42}$

Se considerarmos que a segurança jurídica, a liberdade de locomoção e a moralidade administrativa não chegaram a ser amplamente discutidas, com base em teorias "gerais", nos casos apresentados, poderíamos concluir que estivemos diante de acordos sobre resultados, mas não sobre as teorias que os fundamentam. As diferenças dos casos, apuradas por um raciocínio que se assemelha às analogias propostas por Sunstein, teriam sido suficientes para que os Ministros deixassem de aplicar as súmulas. Contudo, não podemos saber de antemão quando estaremos diante de uma daquelas "raras ocasiões" em que um raciocínio mais ambicioso torna-se necessário, nem podemos saber exatamente onde está a fronteira que separa, na argumentação de um caso, um princípio de nível inferior ou intermediário de um princípio de nível superior. A teoria de Sunstein reconhece que níveis mais altos de abstração podem ser necessários, e até desejáveis, para a solução do caso, mas não nos fornece elementos para decidir qual teoria deveria ser aplicada nessas situações.

Não se trata, portanto, de saber se os princípios que justificam a aplicação de uma súmula são mais ou menos abstratos, e sim de reconhecer que, ao decidir um caso que envolve essa aplicação, o STF não poderá deixar de examinar os argumentos apresentados pela parte em favor da distinção de sua situação, especialmente quando esteja em jogo a possível violação de um direito fundamental. Embora o exercício das competências do Tribunal esteja constrangido por seus limites institucionais e temporais, os princípios que fundamentam um raciocínio analógico devem ser desenvolvidos de modo suficiente para dar conta das circunstâncias relevantes do caso.

Isso não pode ser compatibilizado com a imposição de barreiras ao processo de interpretação, que estabeleçam um patamar que não deve ser ultrapassado pelos juízes. A elaboração de um princípio que justifique a aplicação do precedente, no curso do raciocínio desenvolvido pelo juiz, pode ser confrontada por argumentos, também baseados em princípios, que destaquem as diferenças entre o caso fonte e o caso objeto, o que obriga a buscar outros princípios comparativamente mais abstratos para chegar à solução, uma vez que não é válido interromper a fundamentação de uma decisão antes que boas razões tenham sido encontradas.

Vale observar que o próprio Sunstein não consegue escapar totalmente de teorias abstratas que sustentam sua defesa dos acordos teóricos incompletos, tal como sua concepção do papel do poder judiciário em uma sociedade democrática, e reconhece que as virtudes desses acordos são parciais diante dos casos que só podem ser decididos - ou bem decididos - se utilizarmos alguma teoria.

A partir de uma visão mais dinâmica do sistema jurídico (SUNSTEIN, 1996, p. 54-58), o autor aponta que os princípios de nível inferior podem ter sua compreensão modificada ou aprofundada com o passar do tempo, tornando difícil a solução de questões que antes não eram contestadas. Nesse processo, os participantes 
da comunidade jurídica buscam sistematizar os diferentes precedentes por meio de considerações de nível superior, a fim de lhes conferir maior sentido ou mesmo provocar mudanças em determinadas áreas do direito.

Embora seja raro que qualquer área do direito seja altamente teorizada, o debate em torno dos princípios de nível inferior pode produzir princípios mais gerais e teorizações mais completas. Nessas circunstâncias, afirma Sunstein, não há nada a objetar em relação ao acordo dos juízes com uma teoria que se revela adequada, contudo, tal teoria provavelmente terá sido desenvolvida por meio da generalização e do esclarecimento de resultados sem uma teoria completa. Em síntese, os juízes devem adotar uma teoria mais completa apenas se estiverem certos de que ela é correta, evitando o risco de cometer erros no futuro. ${ }^{43}$

A teoria de Sunstein, portanto, nos coloca diante de outro problema: a opção não seria exatamente entre princípios de diferentes graus de abstração, mas sim entre os vários princípios que podem fundamentar a decisão do caso. Em uma situação que envolve princípios concorrentes, o raciocínio analógico pode não ser suficiente para decidir a questão. Tal como vimos, a analogia requer, além de encontrar a holding do caso-fonte, justificar por que essas razões se aplicam ao caso objeto, apesar das diferenças existentes. No entanto, poderá haver outros princípios que justifiquem a não aplicação do precedente, apesar das semelhanças existentes entre os casos.

Para que essa decisão não seja arbitrária, deve-se buscar um princípio mais amplo, que abranja os demais e justifique por que a similitude ou a diferença devem prevalecer naquele caso, ou seja, a decisão em favor de um princípio diante de outro também deve estar fundamentada em princípios substantivos.

Nos acórdãos do STF aqui analisados, a comparação entre os precedentes e os casos em tela poderia levar à formulação de um princípio que justificasse a aplicação das súmulas: a ausência de direito ao contraditório do interessado no processo estabelecido entre a administração e o TCU para registro da aposentadoria (SV n. 3); o caráter facultativo da presença do advogado em processo administrativo disciplinar (SV n. 5); e a vedação do nepotismo na nomeação de cargos públicos (SV n. 13). O STF, contudo, entendeu que outros princípios deveriam ter mais peso nos casos, quais sejam: a consolidação de situações jurídicas decorrido o prazo de cinco anos; a exigência de defesa técnica no âmbito do processo penal; a livre escolha de cargos políticos pelo chefe do Poder Executivo. Isso permitiu ao Tribunal destacar as diferenças entre os casos e os precedentes que levaram à edição das súmulas, fazendo analogias entre o servidor aposentado há mais de cinco anos e a parte interessada na anulação ou revogação de ato administrativo pelo TCU; entre o acusado em processo administrativo penal e processo judicial penal; entre Secretário de Estado e Ministro de Estado.

A teoria de Sunstein não nos fornece elementos suficientes para justificar as decisões nos casos em que diferentes analogias podem ser feitas com base nos precedentes, 
o que indica a necessidade de aprofundar os argumentos substantivos em seu favor. Essa preocupação caracteriza a teoria do direito como integridade; ao admitir que um princípio moral pode justificar a não aplicação de um precedente, Dworkin nos leva a examinar não apenas os fundamentos dos precedentes, mas também outros princípios do ordenamento jurídico que possam ser relevantes para a decisão. Essa análise se torna ainda mais necessária diante de situações em que há precedentes divergentes envolvidos na questão.

De acordo com a coerência de princípio exigida pela integridade, a aplicação do precedente depende de que seu fundamento seja adequado àquele caso particular e não entre em conflito com outros princípios. Assim, na interpretação dos precedentes, o juiz deve estar atento às circunstâncias do caso a fim de identificar se há outros princípios, além daqueles que aproximam a situação atual e o caso anterior, relevantes para sua solução. Como essas circunstâncias podem ser analisadas a partir de diferentes pontos de vista, os mesmos elementos serão mais ou menos importantes para a decisão de acordo com os princípios que se ajustarem ao caso, o que poderá exigir que o argumento seja desenvolvido até chegar aos princípios mais fundamentais do ordenamento jurídico.

Isso significa que o julgador deve fazer uma série de perguntas que lhe permitam escrever bem o capítulo que lhe cabe nessa história. Diante da situação em que a parte alega que seu caso é diferente, o juiz deve, em primeiro lugar, identificar se há algum princípio no ordenamento jurídico que fundamente os argumentos apresentados pela parte. Posteriormente, cabe perguntar qual solução do caso é a mais coerente: se aquela que se baseia no princípio que justifica o precedente ou aquela que se baseia no princípio que fundamenta a alegação da parte.

Dentre os casos analisados, podemos encontrar nos dois primeiros um argumento similar para responder à essa questão. Tanto na distinção feita na SV n. 3 quanto na SV n. 5, o reconhecimento de um direito fundamental foi considerado decisivo pelo STF para justificar a decisão: a ameaça de violação à segurança jurídica e à liberdade de locomoção tiveram peso suficiente para fazer pender a balança a favor da não aplicação das súmulas. Nos termos de uma visão dos precedentes como princípios, podemos dizer que sua aplicação não respeita a integridade se acarreta a violação de algum direito fundamental. A interpretação dos precedentes, portanto, deve ser coerente com os direitos que fornecem os princípios mais gerais necessários para decidir em favor das semelhanças ou das diferenças entre os casos.

\section{CONCLUSÃo}

O estudo da jurisprudência do STF sobre súmulas vinculantes demonstra que há várias possibilidades de interpretação dos precedentes no direito brasileiro e a proteção de direitos fundamentais tem sido utilizada como fundamento das distinções 
que levam o Tribunal a não aplicar as súmulas. Dentre as concepções analisadas neste texto, a teoria dos precedentes como princípios defendida por Dworkin oferece a melhor justificativa para esse tipo de jurisprudência, tendo em vista que ela reconhece que a aplicação de precedentes deve ser coerente com o conjunto de princípios relevantes para o caso.

Cabe observar que a profundidade com que os argumentos sobre direitos fundamentais terão que ser formulados dependerá da complexidade do caso e será especialmente necessária diante de situações em que um direito fundamental se contraponha a outro. O tratamento dos precedentes nesses termos, contudo, contribui para que sua aplicação, além de não restringir direito fundamentais, possa levar ao reconhecimento de novos direitos a partir da reflexão sobre os princípios morais e políticos que os justificam.

: ARTIGO APROVADO (02/12/2012) : RECEBIDO EM 09/11/2011

NOTAS

1 Ver, especialmente, o MS n. 24.278. Todas as decisões do STF citadas no decorrer deste trabalho encontram-se disponíveis, na íntegra, em sua página oficial na internet (www.stf.jus.br).

2 O julgamento teve início em fevereiro de 2006, encerrando-se em setembro de 2010. No dia 31 de maio de 2007, um dia após a sessão que deliberou sobre a edição da SV n. 3, o Min. Gilmar Mendes proferiu seu voto em concordância com o Min. Carlos Ayres, o que consolidou o entendimento da maioria.

3 A decisão do TCU fundamentou-se na falta de vínculo empregatício entre o trabalhador e o ente público, no período de 01/04/1970 a 31/07/1973, conforme o art. 111 do Decreto-Lei n. 200/67 c/c o art. $1^{\circ}$ do Decreto n. $66.715 / 70$ e os arts. $2^{\circ}$, parágrafo único, e $3^{\circ}$ da Lei n. 5.539/68. Além disso, a decisão estaria de acordo com a jurisprudência do STF, que exige a prestação de serviço exclusivamente na atividade de magistério para fins de concessão de aposentadoria especial de professor (RE n. 180.150; RE n. 350.916; ADIn n. 755).

4 Lei n. 9.784/99, art. 54; Código Tributário Nacional, arts. 173 e 174; Ato das Disposições Constitucionais Transitórias, art. 39, dentre outras.

5 Para os Ministros que negaram a segurança, a SV n. 3 deveria ser aplicada ao caso, tal como exemplifica a manifestação da Min. Ellen Gracie (STF, MS n. 25.116, p. 184): "No presente caso, (...) o Tribunal sinaliza ao sistema judiciário, de maneira preocupantemente contraditória, pois decide contra a letra da Súmula Vinculante 3 e contra o teor dos precedentes que o embasaram." No mesmo sentido, o Min. Marco Aurélio observou que "Demos ontem o primeiro passo para introduzir, no cenário jurídico, o verbete vinculante e hoje estamos aqui a temperar um verbete vinculante, excepcionando uma cláusula linear que afastou o contraditório. (...) Excetuou-se justamente o encaminhamento inicial da aposentadoria, e estamos agora impondo o contraditório em uma situação em que não houve a homologação. Determinou-se o retorno do servidor ao serviço. Levando em conta esse fundamento e o verbete aprovado no dia de 
ontem, se temperarmos o verbete dessa forma e se nós próprios ficarmos a abrir exceção, não teremos a vinculação como acatada?”. (STF, MS n. 25.116, p. 170).

6 A jurisprudência foi confirmada em outros julgados, por exemplo, MS n. 25.403 e MS n. 24.781. Vale notar que, conforme informado nos autos do MS n. 30.553, o TCU adequou seus procedimentos à jurisprudência do STF.

7 Dentre os precedentes listados, há casos que não trataram de processo administrativo disciplinar, como o AIAgR n. 207.197, sobre ausência de advogado no julgamento de recurso administrativo fiscal, e o MS n. 24.961, que trata de Tomada de Conta Especial pelo Tribunal de Contas da União. Além do julgado que realmente levou à edição da súmula, o RE n. 434.059, apenas mais um precedente se refere a processo administrativo disciplinar, o RE-AgR n. 244.027, em que a decisão mantida pelo STF não envolvia uma sanção grave como a demissão, mas apenas o desligamento de policial militar de Curso de Formação de Oficiais.

$8 \quad$ Ver RE n. 434.059.

9 Súmula n. 343: "É obrigatória a presença de advogado em todas as fases do processo administrativo disciplinar"

10 A pesquisa nos julgados do STF que fazem referência à SV n. 5 demonstra, efetivamente, a existência de vários casos em que se pretendia sua aplicação na esfera criminal. Ver, por exemplo, Rcl. n. 8.827, Rcl. n. 8.830, Rcl. n. 9.107, Rcl n. 9.122, Rcl. n. 9.340, AI n. 838.760 e AI n. 840.465. Também com base na liberdade de ir e vir, o STF tem deixado de aplicar a SV n. 9 (“O disposto no artigo 127 da Lei n. 7.210/1984 (Lei de Execução Penal) foi recebido pela ordem constitucional vigente, e não se lhe aplica o limite temporal previsto no caput do artigo 58.”) a alguns casos, por exemplo, HC n. 94.701 e Rcl. n. 10.820.

11 Dentre os precedentes citados, um deles tratava da vedação do nepotismo somente até o segundo grau (ADIn n. 1521) e outro não se referia ao chamado nepotismo cruzado (MS n. 23.780).

12 A distinção feita pelo STF não contou, entretanto, com apoio unânime. No julgamento da Rcl. n. 6.650, por exemplo, o Min. Marco Aurélio questionou a maioria: "Indago: o Verbete Vinculante n. 13 prevê (...) a possibilidade de nomeação de parente consangüíneo, no segundo grau, para secretaria de Estado? A resposta é negativa. Não se tem, no teor do verbete, qualquer referência a agente político. Aliás versa proibição e não autorização.” (STF, Rcl. n. 6.650, p. 296).

13 As duas reclamações a seguir exemplificam de que maneira o STF interpreta a exceção do "agente político" de acordo com as circunstâncias do caso. Na Rcl. n. 9.098, o Min. Joaquim Barbosa negou a liminar porque teria havido ajuste de vontades para permitir a nomeação de parentes: "De fato, a não aplicação da Súmula 13 ao caso concreto resulta dos elementos fáticos postos à consideração do julgador. Em nenhum momento esta Corte pré-excluiu a aplicação da Súmula Vinculante 13 aos agentes políticos. A vedação ao nepotismo é a todo cargo e função de confiança. No caso dos cargos de natureza política, a nomeação de parentes pode ser tolerada desde que realizada sem fraude a lei ou princípio. (...) Os fatos relatados efetivamente indicam violações graves aos princípios da moralidade e da impessoalidade”. Em outra reclamação, de n. 9.429, não é admitida em princípio a alegação de que os interessados ocupavam cargo de agente político, pois teria havido edição de "oportuna legislação local para alterar a nomenclatura dos cargos ocupados por tais pessoas".

14 Para uma análise de distinções feitas pelo STF no âmbito de decisões tomadas em ADIn e ADC ver Maués (2010).

15 Esse tipo de abordagem, que busca analisar os fundamentos para a aplicação de precedentes no direito brasileiro, tem sido desenvolvido especialmente nos trabalhos de Streck (2009). Ver também Vojvodic; Machado; Cardoso (2009), Maués (2009) e Ramires (2010).

16 Uma identificação similar de três modelos de aplicação dos precedentes é feita em Bankowski; MacCormick; Morawski; Ruiz Miguel (1997, p. 497).

17 De acordo com os limites deste artigo, nos restringiremos à exposição dos elementos indispensáveis de cada teoria para a compreensão dos argumentos que elas apresentam em favor de sua concepção de precedentes.

18 No prefácio da obra, Schauer define seu estudo como um exercício em isolamento analítico (analytic isolation), que não pretende abarcar todos os fenômenos aos quais a palavra "regra" pode ser aplicada, nem examinar seus diferentes usos na linguagem ordinária, mas sim esclarecer o que significa tomar uma decisão com base em regras prescritivas. 
19 Para Schauer, o contraponto das regras prescritivas são as regras descritivas, que estabelecem uma regularidade empírica ou matemática e são usadas para descrever ou explicar o mundo e não para controlar comportamentos. Um exemplo dessas regras seria a lei da gravidade.

20 Schauer reconhece que as regras obrigatórias também podem ser formuladas com o mesmo condicionante, como no caso "Se você não quiser pagar uma multa, não estacione aqui”, mas afirma que, no caso das instruções, há uma escolha genuína entre seguir ou não o curso da ação de parte de seus destinatários.

21 Para Schauer, as numerosas opções postas à nossa disposição pela linguagem fazem com que a generalização seja um processo seletivo, no qual as várias propriedades do particular são, simultaneamente, incluídas e excluídas. Por exemplo, um acidente de trânsito pode ser enquadrado pela polícia na categoria “infração de trânsito”, enquanto o médico poderá enquadrá-lo na categoria "lesão dorsal”. Assim, as generalizações sempre envolvem a supressão de propriedades que, em outro contexto, podem ser consideradas fundamentais.

22 Schauer reconhece que nem sempre as regras são formuladas de modo a separar claramente seus componentes, os quais, inclusive, podem não estar explícitos. Contudo, qualquer regra pode ser reformulada da maneira canônica em que um predicado factual é seguido por um consequente.

23 Esse termo (no original, command) é utilizado pelo autor para se referir apenas a proibições e obrigações particulares, mas não a regras.

24 Schauer associa esse problema à textura aberta que caracteriza a linguagem, resultante de seu confronto com um mundo desconhecido e em constante mutação. Assim, mesmo o termo mais preciso pode se tornar vago diante de experiências que não foram antevistas no momento em que o termo foi definido.

25 Schauer aponta ainda um terceiro problema em que as generalizações da regra não atendem à sua justificação. Como os particulares reunidos por uma generalização divergem com relação à maioria de suas propriedades, exceto aquela tomada como base da generalização, pode ocorrer que um caso particular contenha uma propriedade que não foi considerada relevante pela regra, mas é pertinente em determinada circunstância. Assim, embora a relação probabilística entre generalização e justificação continue sendo válida, ela não se ajusta àquele caso específico. Sem embargo, o autor reconhece que essa terceira situação não é essencialmente distinta das duas primeiras.

26 Para o autor, o enraizamento das generalizações é, em grande parte, um fenômeno psicológico, que faz com que as particularidades que foram suprimidas sejam menos acessíveis à mente do que supõe o modelo da conversação. Assim, as generalizações moldam nossa imaginação e restringem nossa capacidade de observar propriedades diferentes.

27 Schauer observa que o enraizamento possui consequências similares nos casos de subinclusão. Imaginemos que, no mesmo restaurante, alguém pretendesse entrar com seu urso de estimação. Se o predicado da regra for tratado como algo enraizado, ursos poderiam entrar no restaurante, pois não estariam incluídos naquele predicado, embora isso não seria o resultado indicado pela aplicação direta da justificativa da regra.

28 Apesar dessas semelhanças, Schauer reconhece que a generalização/predicado factual do precedente precisam ser construídos a partir da decisão anterior, ao passo que já se encontram formulados nas regras. Para o autor, tanto a descrição dos fatos do precedente, sua fundamentação, quanto às categorias por ele utilizadas, podem servir como generalizações e, portanto, conter o predicado factual de uma regra que deve ser aplicada.

29 Com base em sua análise das regras, Schauer (1991, p. 196-206) propõe uma nova versão do positivismo jurídico, chamada por ele de positivismo presuntivo. Para o autor, o positivismo trata o direito como um sistema de regras cuja validade independe de sua coerência com as demais normas de cunho moral e político presentes na sociedade, Isso não significa, no entanto, que somente regras jurídicas sejam aplicadas pelos juízes, nem mesmo que elas sempre devam ser aplicadas ao caso. Para que o positivismo descreva de modo preciso os sistemas jurídicos, é necessário apenas que haja prioridade no resultado produzido por essas regras, mesmo em situações que contrariem suas justificativas, o que permite caracterizá-las como proporcionalmente dominantes.

30 Tal como Schauer, Sunstein reconhece que casos incomuns podem surgir, como alguém que ultrapassa o limite de velocidade porque precisa levar um amigo ao hospital ou um policial que entra com um cão farejador no restaurante por causa de uma ameaça de bomba. Nesses casos, porém, Sunstein observa que não é possível tomar uma 
decisão somente com base na semântica da regra, sendo necessário que o julgador desenvolva juízos de cunho moral e político.

31 Além do raciocínio analógico, Sunstein também destaca a importância dos julgamentos particularistas no direito, guiados pela avaliação do conjunto de fatores considerados relevantes para o caso.

32 No mesmo sentido, cf. Streck (2009, cap. 10 e 11) e Cruz (2007, cap. 6).

33 Dworkin propõe como exemplo uma convenção que obrigue os juízes a garantir a ambas as partes iguais oportunidades de defender sua causa. Todos concordam que isso significa que elas devem ser ouvidas, o que constituiria a extensão explícita da convenção, mas discordam se isso significa que ambos devem dispor do mesmo tempo, mesmo que os argumentos de um lado sejam mais complexos do que do outro, ou exijam um maior número de testemunhas. Assim, embora haja concordância sobre a extensão explícita, há divergência sobre se a extensão implícita inclui ou não tempos iguais para as partes.

34 Em trabalho posterior, Schauer (2003, cap. 8) argumenta que a igualdade exige que casos diferentes sejam tratados como iguais, usando as generalizações contidas nas regras.

35 Schauer exemplifica essa situação com a pena de morte. Quando ela é imposta de acordo com regras estritas, temos condições de antecipar os atos aos quais a sanção será aplicada. Essa previsibilidade, porém, é obtida sob o risco de executar pessoas que poderiam viver caso seus atos fossem analisados de modo mais detalhado.

36 Schauer observa ainda que os argumentos da confiança, da eficiência e da aversão ao risco valorizam a estabilidade. À medida que os resultados sub-ótimos são vistos como um preço que vale a pena pagar em razão das vantagens que advêm das restrições impostas pelas regras, mudanças no statu quo - seja para pior, seja para melhor - tornam-se mais difíceis do que seriam caso os agentes fossem livres para se afastar das categorias e prescrições do passado. Contudo, o autor reconhece que essas questões tampouco podem ser respondidas fora de um contexto social ou político particular, dentro do qual poderemos saber se a estabilidade e a manutenção do statu quo é algo bom e, portanto, avaliar se o argumento da estabilidade é um argumento persuasivo em favor das regras. Assim, as virtudes das regras provavelmente serão mais reconhecidas quando houver uma visão amplamente positiva do statu quo, em que os danos provocados por uma desestabilização são considerados maiores que seus benefícios.

37 Para Schauer (2007), um tribunal que lida constantemente com questões de cunho moral e político, tal como a Suprema Corte norte-americana, tende a não utilizar precedentes para fundamentar suas decisões. Cabe observar que o aparecimento de experiências recalcitrantes no direito contemporâneo é muito mais comum do que o modelo de Schauer parece supor. Como lembra Sunstein (1996, p. 122-124), mesmo palavras aparentemente claras podem depender de argumentos morais e políticos para serem aplicadas.

38 No âmbito do direito norte-americano, Hershovitz (2006) demonstra que a vinculação de um tribunal a seus próprios precedentes (horizontal stare decisis) não exige que ele mantenha decisões que se mostrem posteriormente equivocadas, mas sim que ele apresente as razões pelas quais o precedente não será aplicado.

39 A recusa em desenvolver argumentos de princípio leva Sunstein a defender, em seus trabalhos posteriores, que as decisões judiciais devem ser minimalistas, baseando-se nas circunstâncias do caso e evitando estabelecer regras amplas para o futuro (Sunstein, 1999).

40 Exemplos de teorias de nível superior seriam o kantismo e o utilitarismo, ou os esforços de alguns juristas que buscam compreender os institutos jurídicos formulando teorias bastante abstratas sobre o "bem” e o "justo".

41 Sunstein afirma ainda que os acordos teóricos incompletos promovem dois objetivos típicos da democracia e do sistema jurídico liberal: contribuem para que as pessoas vivam juntas e demonstrem reciprocidade e respeito mútuo umas às outras, por tornarem desnecessário lidar com questões em que há divergências fundamentais entre elas. Da parte dos juízes, o respeito às convicções mais profundas dos demais significa que eles não devem se envolver com elas, a menos que seja indispensável para a solução do caso. No entanto, Sunstein reconhece que algumas convicções devem ser questionadas quando se colocam à margem do sistema jurídico, como aquelas que rejeitam a dignidade humana ou outros direitos fundamentais. 
42 Sunstein estende suas críticas a autores que, como Dworkin, defendem o uso de teorias mais abstratas no raciocínio judicial. Além desse tipo de teoria estar muito afastada da prática real dos juristas, ela não seria adequada ao papel limitado que os juízes devem exercer em uma sociedade pluralista. Para a réplica, ver Dworkin (2006, p. 65-72).

43 As circunstâncias em que os juízes devem buscar teorias mais ambiciosas são desenvolvidas posteriormente por Sunstein (2008), sem que isso represente um abandono de sua defesa dos acordos teóricos incompletos.

\section{REFERÊNCIAS BIBLIOGRÁFICAS}

BANKOWSKI, Zenon et al. Rationales for Precedent. In: D. Neil Maccormick; Robert S. Summers. (Orgs.) Interpreting Precedents. A Comparative Study. Aldershot: Ashgate, 1997.

CRUZ, Álvaro Ricardo de S. Hermenêutica jurídica em debate. Belo Horizonte: Fórum, 2007.

DWORKIN, Ronald. Levando os direitos a sério. São Paulo: Martins Fontes, 2002. O império do direito. São Paulo: Martins Fontes, 1999.

. Justice in Robes. Cambridge: Harvard University Press, 2006.

HERSHOVITZ, Scott. Integrity and Stare Decisis. In: Scott Hershovitz. (Org.) Exploring Law's Empire. The Jurisprudence of Ronald Dworkin. Oxford: Oxford University Press, 2006.

MARINONI, Luiz Guilherme. Precedentes obrigatórios. São Paulo: Revista dos Tribunais, 2010.

MAUÉS, Antonio Moreira. Súmula Vinculante e Proteção dos Direitos Fundamentais. Direitos Fundamentais \&Justiça, n. 8, p. 81-96, jul./set. 2009.

O controle de constitucionalidade das leis no Brasil como um sistema plural. Pensar, v. 15, n. 2, p. 356-384, jul./dez. 2010.

MELlO, Patrícia Perrone Campos. Precedentes. O desenvolvimento judicial do direito no constitucionalismo contemporâneo. Rio de Janeiro: Renovar, 2008

RAMIRES, Maurício. Crítica à aplicação de precedentes no direito brasileiro. Porto Alegre: Livraria do Advogado, 2010 .

SCHAUER, Frederick. Playing by the Rules. Oxford: Clarendon Press, 1991.

. Profiles, Probabilities and Stereotypes. Cambridge: Harvard University Press, 2003.

. Has Precedent Ever Really Mattered in the Supreme Court? Georgia State University Law Review, v. 24, p. 381-401, 2007.

STRECK, Lenio Luiz. Verdade e consenso. 3. ed. Rio de Janeiro: Lumen Juris, 2009.

SOUZA, Marcelo Alves Dias de. Do Precedente Judicial à Súmula Vinculante. Curitiba: Juruá, 2006.

SUNSTEIN, Cass. Legal Reasoning and Political Conflict. Oxford: Oxford University Press, 1996. One Case at a Time. Cambridge: Harvard University Press, 1999.

. Beyond Judicial Minimalism. Tulsa Law Review, v. 43, p. 825-841, 2008.

VOJVODIC, Adriana de Moraes et al. Escrevendo um romance, primeiro capítulo: precedentes e processo decisório no STF. Revista DireitoGV, v. 5, n. 1, p. 21-44, jan./jun. 2009.

Antonio Moreira Maués

UFPA - Inst. de Ciências Jurídicas Rua Augusto Corrêa, n. 1 66075-110

Belém - PA - Brasil ammaues@uol.com.br
Professor Associado da Universidade Federal do Pará Pesquisador do Conselho Nacional de Desenvolvimento Científico e TECNOLógico 
